\title{
“... por decir Dios Trino y Uno, dijo Dios tres y uno son cuatro” - The Christian Trinity and the Multiplicity of Andean Deities: Indigenous Beliefs and the Instruction of the Christian Doctrine in Quechua
}

\author{
Sabine Dedenbach-Salazar Sáenz \\ University of Stirling (Scotland)
}

Published in March 2017 as:

Dedenbach-Salazar Sáenz, Sabine: ' ... por decir Dios Trino y Uno, dijo Dios tres y uno son cuatro': The Christian Trinity and the Multiplicity of Andean Deities: Indigenous Beliefs and the Instruction of the Christian Doctrine in Quechua. In: Colonial Latin American Review 25/4 (2016): 414-444.

$<$ http://dx.doi.org/10.1080/10609164.2016.1281004>.

\begin{abstract}
In this paper I examine how Christian priests in the early colonial period in the Andes tried to communicate the Christian concept of the Trinity to the indigenous population, mainly through textual but also through visual means. On the basis of these sources, I will address the following questions: how did the priests present the concept in Quechua, one of the general languages of the Andes, in morphological, lexico-semantic and argumentative terms; how was the Trinity represented in painting and, could the Indians relate these explanations to something they were familiar with in their own religion? Answering these questions will provide us with hypotheses as to how the indigenous population might have understood this Christian concept, which, in turn may enable us to better understand modern Andean belief forms with respect to the Trinitarian concept, which I shall briefly discuss in the final section. On the whole, the evidence suggests that, whilst the Christians may have thought that they could explain their Trinity to the Andean people better by using the Quechua language, the adoption of Andean concepts and language resources resulted in different reception strategies, such as the accommodation of Christian beliefs in the Andean religious system, but also the creation of new hybrid concepts based on Amerindian as well as Christian belief forms.
\end{abstract}




\section{Introduction}

“... por decir Dios Trino y Uno, dijo Dios tres y uno son cuatro", 'in order to say God is Triune and One, he said God three and one are four' - this was put by the chronicler Garcilaso de la Vega into the interpreter Felipillo's mouth when he had to translate the Spanish priest Valverde's words for the Inca Atahuallpa. ${ }^{1}$ This misunderstanding calls our attention to the problems related to conversion: right from the beginning of the European conquest there were misunderstandings, in this case based on the wrong translation and possibly - as in many other cases - due to the difference in European and Andean religious experience. ${ }^{2}$

From the colonizers' point of view for the successful conversion of the native peoples it was necessary to explain one of the basic and most important as well as most complex concepts of Christian religion, that of a triune god. It is essential to a real understanding of Christianity and part of important rites such as baptism and making the sign of the cross. $^{3}$

\section{2.}

\section{The Christian doctrine in Europe: The Roman Catechism}

The theological interpretive framework which was available to the priests who worked in the Americas was the so-called Catecismo Romano, a catechism produced on the initiative of the Tridentine Council (Rodríguez and Lanzetti 1982, 1985). First published in 1566, it was edited many more times during the following centuries. It is a manual for parish priests which explains in a detailed way the Articles of Christian Faith, the Sacraments, the Ten Commandments and the prayers. It is explanatory in

1 Garcilaso de la Vega ([1617] 1960, vol. 3, libro I, cap. XXIII, p. 48). Atahuallpa follows up on the erroneously interpreted argumentation by reportedly saying: "Demás de esto me ha dicho vuestro faraute que me proponéis cinco varones señalados que debo conocer. El primero es el Dios Tres y Uno, que son cuatro, a quien llamáis Criador del Universo, ¿por ventura es el mismo que nosotros llamamos Pachacamac y Viracocha? El segundo es el que dices que es Padre de todos los otros hombres, en quien todos ellos amontonaron sus pecados. Al tercero llamáis Jesucristo, sólo el cual no echó sus pecados en aquel primer hombre, pero que fué muerto. Al cuarto nombráis Papa. El quinto es Carlos ..." (ibid. p. 51).

2 For a study on the Trinitarian concept of God in the colonial Andes from a theologicalmissionary point of view see Delgado (1992).

3 Furst (1998: 209-212) gives a summary of the early development and understanding of the Trinity in Europe. 
character and gives arguments in favor of or against certain interpretations of Christian religious concepts.

The concept of the Trinity is presented in this catechism in the framework of the Articles of Faith (the Apostles' Creed) and uses the term 'one essence of God' ("vna divinitatis essentia"), but manifest in 'different persons' ("personarum distinctionem"): ${ }^{4}$

The Father then is unbegotten; The Son is begotten of the Father: the Holy Spirit proceeds from both. And so we confess the same essence, the same substance of the three Persons; so that we believe, in a pious and saintly way, in the confession of the true and eternal God, and in the distinction in the Persons, and in the unity in the essence, and in the equality in the Trinity.

... that the parish priests may teach that it is obligatory to maintain the word of the essence and the distinct persons, which convey that mystery, and the faithful may know that the unity is in the essence, but the difference is in the Persons. ${ }^{5}$

It is explicitly negated that one of the three persons is anterior or posterior to the other; and it is considered neither necessary nor recommendable to explore this secret beyond the explanation given in the catechism (ibid., 25-26).

This was then the explanation and instruction available to the European priests when they found themselves confronted with the necessity of explaining this concept to the American native people. ${ }^{6}$

4 All translations from Quechua and Latin texts into English are mine (SDS).

5 Catechismus ex Decreto Concilii Tridentini 1567, 24-25; translation by SDS, terminology from the Roman Catechism $(1985,26)$. Latin version: "Pater siquidem ingenitus est: Filius à patre genitus: Spiritus sanctus ab vtroque procedit. Atque ita trium personarum eandem essentiam, eandem substantiam confitemur; vt in confessione veræ sempiternæ quæ deitatis, \& in personis proprietatem, \& in essentia vnitatem, \& in trinitate æqualitatem pie, \& sancte colendam credamus. ... doceat Parochus, religiose retinenda esse essentiae, \& personæ propriæ vocabula, quibus hoc mysterium significatur, \& sciant fideles vnitatem esse in essentia, distinctionem autem in personis."

6 The difficulty in understanding the concept of the Trinity was also object of the Jewish conversos' writings and Christian theologians' answers (Da Costa Fontes 2005, 53-37 and 202-230). 


\section{The Christian doctrine in the Americas}

\subsection{The Middle American catechisms for the indigenous people}

With respect to the Americas, it has to be considered that the first experience of conversion took place in Middle America and is especially well documented for Mexico where the Franciscan order had a leading position in the theory and practice of catechization. Let us therefore first look briefly at the Mexican catechisms.

Preceding (and then accompanying) the written catechisms, some Christian priests used canvas paintings which they explained with gestures or with the help of an interpreter, and later directly in the indigenous languages. Another means of conveying Christian beliefs were pictographic codices (also called 'testerianos', after Jacobo de Testera), the most famous one made by Pedro de Gante (ca. 1525-28). ${ }^{7}$ An important aspect of this kind of catechization is the combination of oral and painted components which show that an interpreter - in the sense of explaining as well as translating - was necessary (as becomes clear from Gante's illustrations, see Ill. 1).
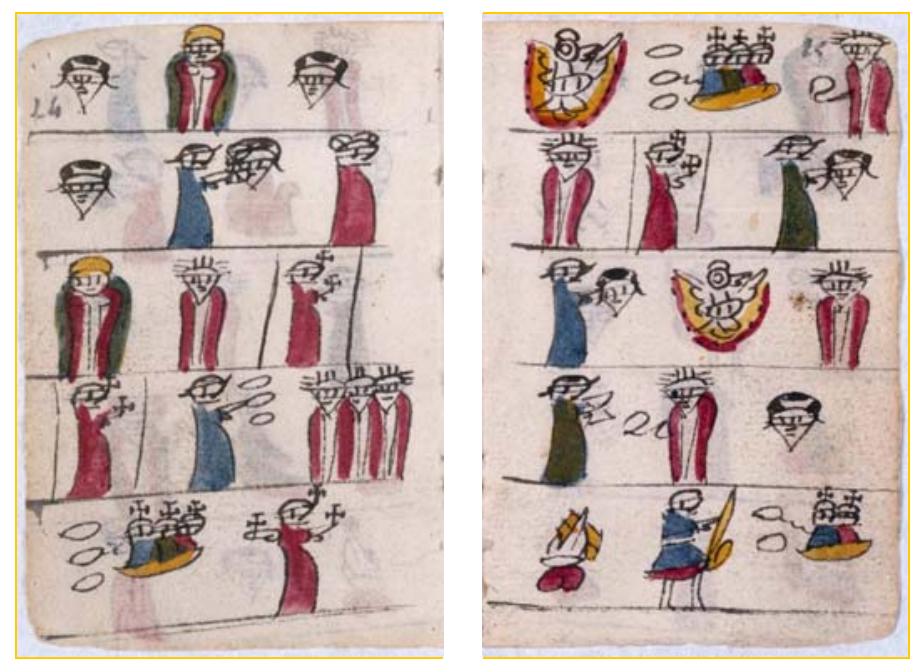

Illustration 1: Pedro de Gante:

Catecismo de la Doctrina Cristiana ([ca. 1525-28]: 24-25)

In his study of the lexical devices used for the expression of the Trinity in Nahuatl by early missionaries in Mexico, Tavárez (2000) shows that there was no single policy. ${ }^{8}$ In

7 Cf. Durán (1984, vol. 1, 67-167). Pictographic presentations of parts of the catechism are also documented for the Southern Central Andes, made of paper, leather, stone or clay. They are difficult to date, but go back at least to the 19th century (Hartmann 1991).

8 Cf. also Furst (1998) for her observations about the Trinity and the nature of the soul in ancient Mexico. 
terms of the names of the elements of the Trinity, the Nahuatl words for 'father' and 'son' were used to accompany the Spanish loanword 'Dios', and 'Dios Spiritu Sancto' was kept in its Spanish form. 'Persona' was also used as a loanword, as well as 'Santísima Trinidad'; and lexical and morphological items such as 'self', 'truly', 'separately' and the honorific morpheme and gross number plural were all possible solutions for coping with the complexity of the concept. What becomes clear from Tavárez' analysis is the variety of possible expressions, also documented in the opening formula of testaments written in Nahuatl.

With respect to the conceptualization, the Mexican priests - some of whom wrote their texts before the publication of the Roman Catechism - used formulations very similar to this standard work, but in their catechisms more concrete images can be found in order to convey the Trinitarian concept, as can be seen in the following examples.

Dionisio de Sanctis says in 1575: "Que Dios con ser uno en su esencia, es tres personas distintas: la primera, es el Padre; la segunda, el Hijo; la tercera, el Espíritu Santo; que es lo que llamamos Santísima Trinidad, tres Personas y un solo Dios verdadero."9 Pedro de Córdoba (1544), on the other hand, applies images of visualization to explain the Trinity: “... así como el hombre es una naturaleza y esta naturaleza está en muchas personas ... y así muchas personas son una naturaleza, y asimismo la naturaleza de la piedra está en muchas piedras, y todas ellas tienen una naturaleza que se llama piedra .... Y así Dios que es una naturaleza, como ya es dicho, está en muchas personas: conviene a saber en tres." ${ }^{10}$ Córdoba goes on to compare the Trinity with different objects of our world, among them a textile with many folds, and the sun and its rays. This latter image seems to have been of common usage because Juan de la Asunción, in his AztecSpanish catechism, mentions other "saints", i.e. saintly persons, and their efforts at interpreting the Trinity by means of similes: "así como el sol produce rayos de luz sin estar dividido, ni ser más que un sol, así podemos decir, por vía de comparación, que Dios Padre, Luz Eterna, de su sustancia y ser produce y engendra a su único Hijo, Jesucristo."11

9 Dionisio de Sanctis: Breve y muy sumaria instrucción ..., Cartagena 1575 (?), Los artículos de la fe, in Durán (1984, vol. 1:578).

10 Pedro de Córdoba: Doctrina cristiana para instrucción e información de los indios, México 1544, Los artículos de la fe, in: Durán (1984, vol. 1:233-234).

11 Juan de la Asunción: Catecismo en lengua mexicana y española, México 1577, Los articulos de la fe, in: Durán (1984, vol. 1:636). 
On the basis of these data we see that there was no common and generally accepted explanation and that the authors used abstract as well as concrete figurative explanations in order to convey this complex concept.

\subsubsection{The Lima Provincial Councils of the 16th century: Guidelines}

Whilst in Mexico the Franciscans were the leading missionary order, in Peru the Jesuits had this role. The First Lima Council (1551) explicitly refers to the Roman Catechism saying: "Dios es Padre, hijo y espíritu santo tres personas y un solo Dios verdadero" (Vargas 1951, vol. 1, 324). This instruction is directly related to indigenous beliefs when, in another paragraph, it says: "Decirles cómo hay un solo Dios, Padre, Hijo y Espíritu Sancto; y no tres dioses sino uno solo, porque tiene un ser y un querer y un entender, el cual es sin principio ni fin" (Mateos 1950a, 48). Such an instruction for priests implies that already twenty years after the conquest the Church supposed that the indigenous people believed in a multiplicity of deities and multiple gods. This may have been based on the Mexican experience, but it is probably also already a reflection of missionary work in the Andes themselves.

The Second Council (1567) takes these formulations up again: "being one God, the Father, the Son and the Holy Spirit, it is obvious, the creator of man, heaven and earth as well as everything." 12

The Third Lima Council refers explicitly to the danger of misinterpreting the threefold Christian god by describing the correct concept in contrast to the supposed deceit by the Devil or the invention of their own gods by non-Christians: "moreover, that same God is the father and the son and the holy spirit, certainly three persons, but one true God, beyond whom there is no other true God, because what other non-Christian peoples adore is not God, but demons or rather inventions made by human beings." 13

12 "esse unum Deum, Patrem, Filium et Spiritum Sanctum, scilicet, hominum, caeli terraeque et omnium rerum creatorem" (Constitutio 33, Mateos 1950b, 549).

13 "deinde hunc ipsum Deum esse patrem et filium et spiritum sanctum, tres quidem personas sed unum Deum verum, præter quem nullus alius sit verus Deus, nam quæ adorant aliæ gentes præter Christianam non esse deos sed dæmones potius aut figmenta hominum" (Acción 2, cap. 4, Lisi 1990, 126); Spanish translation by Lisi (1990, 127): “además, que este mismo Dios es el padre, el hijo y el espíritu santo, tres personas, pero un único Dios verdadero y que salvo él no hay ningún otro dios verdadero, pues lo que adoran los otros pueblos no cristianos no son dioses, sino demonios o más bien ficciones de los hombres". 
José de Acosta, who was in charge of the texts of the Third Lima Council, had already in 1577 declared it important that the indigenous population be taught what the concept of the Trinity meant. The main reason was its importance as the basis for baptism (Acosta [1577] 1987, vol. 2, libro V, cap. VI, p. 228-229, paragraph 1). Also, Acosta argues, just like the Indians, the theologians do not and cannot have a clear understanding of what the mystery of the Trinity really is because it is not a matter of understanding, but of belief (ibid., 230-231, paragraph 3). He thinks that it is not only Indians and blacks who do not know what it means that there are three persons in one essence, and that nobody must be excluded from the necessary knowledge of the Trinity (ibid., 232-233, paragraph 5). Based on St. Augustine, he says that the distinction in the persons, the unity in the essence, and the equality in the majesty has to be adored. ${ }^{14}$ It is therefore necessary to teach everyone to belief in one God the Father, the Son and the Holy Spirit, in the way he is venerated in Christian religion. ${ }^{15}$

Although the conceptual framework of the Trinity was certainly the same in 16th century clerical thinking, the way of explaining it seems to have differed in that Mesoamerican missionaries took a more concrete approach (visual images and oral imagery) whereas the Jesuits of Peru tried to convey the rather abstract concept as such.

Let us now look at the catechisms of the doctrinal texts which were the outcome of the Third Lima Council.

\subsubsection{The Third Lima Council (1582/83): The Doctrina Christiana (1584) and later doctrinal texts}

The Articles of Faith of the 1584 Lima Doctrina Christiana are the first expression in Quechua of how the Christian god is conceived: "huc çapalla Dios llapa atipacman "16", 'one God alone being completely powerful' (in Spanish: "vn solo Dios todo poderoso", Los articulos de la fe, primer artículo, fol. $4 \mathrm{r}-\mathrm{v}$ ). Here the qualifying words $h u k^{17}$, 'one',

14 Acosta ([1577] 1987, vol. 2, libro V, cap. VI, p. 234, paragraph 6): "ut in personis proprietas, in essentia unitas, in maiestate adoretur æqualitas".

15 As Acosta ([1577] 1987, vol. 2, libro V, cap. VI, p. 234, paragraph 7) writes: "Opus ergo est ut omnes doceantur credere in unum Deum Patrem et Filium et Spiritum Sanctum, quemadmodum religio christiana veneratur".

16 The function of the directional suffix -man is not clear in this phrase.

${ }^{17}$ In the discussion of the Quechua words a modern orthography based on Ayacucho Quechua is used. For grammatical explanations I have mainly consulted González Holguín (1607) and Hoggarth (2004); for the words González Holguín ([1608] 1989) and Lira (1945). 
sapa, 'only, unique' as well as the limitative suffix -lla are established to be used continually in different parts of the work. In the 'short catechism' another expression is added: "huc cayniocllam", 'one alone who possesses being' (in Spanish: "vn mismo ser", Catecismo breve, fol. 13v), nominalizing and thereby forming an abstract meaning of the verb 'to be' (ka-).

Whilst the unity of this god's being is emphasized by the mentioned linguistic means, the multiplicity of the same god is expressed by using the Spanish loanword persona: 'God the Father, the Son and the Holy Spirit are three persons one God alone', "quimça persona huc çapalla Diosmi" (in Spanish: "son tres personas y vn solo Dios", Catecismo breve, fol. 13v). In order to emphasize this unity, the numeral kimsa, 'three', is connected with -ntin, a suffix which expresses that two or more things are closely interrelated: "quimçantin persona"18 (in Spanish: "todas tres personas" (ibid.)). The usage of persona instead of the Quechua word runa, which expresses exactly the same thing, that is 'person', may be due to the other meanings runa also has and which are 'man in the sense of a male being' and 'human being' in general. ${ }^{19}$ However, Molina, in the sermon ascribed to him by Guaman Poma, uses runa for the Trinity (see below, section 3.3) - either Guaman Poma or Molina did not want to or know to make the distinction.

In his dictionary González Holguín ([1608] 1989: 627) proposes constructions with perfective nominalizations of ka-, 'to be (in a place)', and tiya-, 'to live (in a place), to sit': "Persona en Dios assi como dezimos Dios caynin el ser de la essencia, asi Diospa cascan o tiyascan caynin, el ser personal de la existencia que es las personas, porque, Cani, o tiyan es estar o existir en si", literally 'the being/state of God's existence, or being [in him]'. He rejects a construction with saya(-), 'to stand upright; height' because only human beings can have a stature: "Persona Diuina, no es, ni ay Diospa sayaynin, que no ay en Dios sayay, que es estatura, sino en Christo solo por ser hombre, y en el angel no ay sayaynin, sino es quando aparece en cuerpo visible." However, in 1631 Pérez Bocanegra tries to explain the Trinity in his Ritual formulario (2012, Quechua p. 656, Spanish p. 649) using this same word. Like the Doctrina he differentiates the three persons using the Spanish loanword persona, but instead of making them a unit (with -

18 I have completed all abbreviated forms in the Spanish and Quechua words without indicating this in my quotations, e.g. "quimçãtin" becomes "quimçantin".

19 The dictionary which accompanied the Doctrina Christiana texts explicitly stated (s.v.): "Persona en la sanctisima Trinidad, persona no no [sic] ay termino en la lengua que le equiualga", after giving "Persona. runa" for the general meaning (Arte, $y$ vocabulario ... quichua 1586, s.v. persona). 
ntin) he adds three further terms: sayaq, 'standing, upright', chiqanpi, 'in truth', but also 'on its own', and raki-, 'to distribute, to divide', which seem to emphasize the distinctness rather than the unity of the three persons: "Diospica ari, pana huc cayñiyoc caspapas, quimça sayac(,) personamanmi, checampi raquicun". 'In God then, although he is one being, he is [truly] divided into three upright persons [each on its own]' (in his own words: "Porque en Dios, con ser vno en esencia, y naturaleza; ay tres personas naturalmente distinctas") ${ }^{20}$; this is then followed by the description of how the one is not the other.

We notice that after the Doctrina Christiana translations, which were meant to be the only authorised teaching manual so as to avoid individual interpretations (Lisi 1990, Acción segunda, cap. 3, 124-125), some priests tried to make the concept clearer employing different linguistic means. It may be doubted whether their explanations were more comprehensible, and as contemporary catechisms employ the earlier, 16th century translation, they may have not been taken up by other colonial priests. ${ }^{21}$ What the variety does show is that the Peruvian missionaries did not simply copy each other or the Mexican examples. And it is for us to speculate what the indigenous people understood when a new and unknown religious phenomenon was explained to them by words equally unknown by them or constructions which may not have reflected Quechua syntax and metaphorical meaning correctly.

With respect to the strategy for argumentation, the Doctrina Christiana texts use the negation construction 'A manam B-chu', 'A is not B', in order to explain the three persons of the Trinity: "Cay quimçantin personamanta Dios yayaca manam churichu, manatacmi Spiritu sanctochu", 'From these three persons together God the father is not the son, and certainly not the Holy Spirit either.' (in Spanish: "Porque de estas tres personas el Padre no es el Hijo, ni el Spiritu sancto", ibid.).

The way in which ambiguities can creep into a translation becomes evident when we look at the more detailed Quechua explanation in the Catecismo mayor (fol. 30v): "sin que aya en ellas [estas tres personas] mayor ni menor; y no ay otro Dios sino aqueste / Cay quimça personamantari, manam maycannimpas hucninta yallinchu, cuscacamallam,

${ }^{20}$ His use of the locative -pi in Quechua (to translate "in God") shows that he did not think the Quechua structure through completely, but based the beginning of the sentence on his Spanish formulation.

${ }^{21}$ In the contemporary catechetical Southern Peruvian Quechua texts available to me, dating from the second half of the 20th century, the words sapa, kimsa and persona are always used; the grammatical constructions vary a little (Flores de Palacios et al. 1976, 76, Molloy and Sutta 1967, 63; Doctrina cristiana en quechua 1969?, 32-33). 
pactapunillam, manatacmi huc huc Diosca canchu", which translates from the Quechua: 'and from these three persons, there is not any one that exceeds the others; all of them are just the same; watch out: there is certainly no other god'. It is doubtful whether the message of the last sentence was clear: huk means 'one' and 'another' and a reduplication normally intensifies the meaning of the word so that one may also understand: 'There is certainly not one single God'.

As far as the vocabulary for the Trinity is concerned, 'Father' and 'Son' are translated into Quechua, with the appropriate words of this language denoting fatherhood of a man towards a child, churi denoting a female or a male child, without specifying the gender. 'Holy Spirit', however, is never translated into Quechua; the Spanish is used as a loanword, adapted to its specific grammatical environment by adding Quechua suffixes to it when necessary. Thus the direct meaning in Quechua would have been 'Father, Child, Espíritu Santo' (just as in Mexico, Tavárez 2000, 25), with the third element of the Trinity being the most difficult one to understand unless we think of the numerous paintings the native population could see in the churches. Those, however, represented the Holy Spirit sometimes as a dove and sometimes as a human person and may therefore have produced more confusion than clarification (see 3.4).

\subsubsection{The Third Lima Council (1582/83): The sermons of the Tercero Cathecismo (1585)}

Apart from the more formal and ritualized texts of the Doctrina Christiana the Lima Council also created a collection of sermons, the Tercero Cathecismo, thought as model for the priests' usage, which explained basic concepts of the Christian faith.

Sermon V (fol. 27v-33r) is dedicated to the topic of God's identity. It uses the same morphological and lexical devices as the Doctrina texts, but it explains the argument in a more detailed way. Having said that there is one god alone, the translator adds a phrase in Quechua which is not in the Spanish text and which emphasizes the worry about a possible misunderstanding in a polytheistic sense: "Manam ari Diosca yscaychu quimçachu”, 'So God is neither two nor three' (ibid., fol. 29r).

In what follows it is denied that there can be gods with certain functions each or for certain groups of people, and such beliefs are ascribed to the indigenous people's ancestors (ibid., fol. 29r). It is then emphasized that there is only one god (ibid., fol. 29r) and monotheism is justified by saying that there would be chaos if there was more than one god (ibid., fol. 29v). The author repeats God's qualities in terms of him being one god alone, but of three persons, although - and this is only said in the Quechua text 
- these are not three gods or three powerful men (ibid., fol. 31v). Just as in the Doctrina texts, this nature is explained through negation, A manam B-chu, but - it reads - the three persons own 'one single being, one power, one will, one living' (ibid., fol. 32r). Then the theoretical question is asked how this is possible and the answer is that the nature of God's things is incomprehensible because they are his (ibid., fol. 32r); this coincides with the Roman Catechism (cf. also Acosta above). At the end, the author of the sermon uses for the first time the word "Trinidad", in the Spanish and in the Quechua text; he equates this with three persons (in Quechua the absence of the third person singular of ka-, 'to be' is grammatically obligatory): the Father, the Son and the Holy Spirit: "Y, cay santissima Trinidadmi. quimça persona Yaya, Churi, Spiritu sancto", (in Spanish: "que en esta sanctissima Trinidad, ay tres personas distinctas, que se llaman Padre, y Hijo, y Spiritu sancto", ibid., fol. 32r-v). In the Spanish text "Trinidad" is explained as the "mysterio de la sanctissima Trinidad"; however, the Quechua text does not give a translation for 'mystery'; it is simply omitted (ibid., fol. 32r). Further down, when the word "mysterio" is used again in the Spanish text, the Quechua equivalent given is $f e$ : "Este mysterio protestamos ...", "Cay fectam yñinchic ..." (ibid., fol. 33r). Fe is - on other occasions - also used in Quechua with its original Spanish meaning, that of 'belief' (for example by Oré [1598] 1992, Primer cantico, fol. 70r). The usage of the terminology is therefore confusing, and it seems to me that here an opportunity is lost when the translator is unable to come up with a Quechua word that might imply the meaning of 'mystery'. ${ }^{22}$ A Quechua equivalent for 'mystery' when it refers to the Trinity would have complied very well with Acosta's idea of the Trinity being something which is not comprehensible by reason.

Sermon V (fol. 32v) also explains that the three persons are equal and repeats the affirmation of one god alone by negating the identity of the three (marked with italics and underlining by SDS): "Creemos y confessamos que siendo tres personas distinctas, de suerte que cada vna no es la otra, pero no son tres Dioses, ni tres señores, ni tres poderes, sino vn solo Dios y Señor, ... / Y, quimça persona caspapas, $\underline{\underline{\text { manam }}}$ maycannimpa personam, hucnimpa personanchu, ychaca manam quimça Dioschu, manam quimça capacchu, manam quimça atipayniocchu, huc Diosllam, huc çapay capacllam." The Quechua reads in English: 'And, although they are three persons, they

22 Interestingly enough, neither the dictionary which accompanied the Doctrina Christiana (Arte, y vocabulario ... quichua 1586) nor Santo Tomás ([1560] 1951) or González Holguín ([1608] 1989) have translations of the word 'mystery'. 
are / he is not of which one the person, not of the other one his person ${ }^{23}$, but they are not three Gods, not three powerful beings, not three powers, only one God, only one powerful being alone.'

The Quechua passage and my English translation show the complexity of the argument: the subordination and conjunction (marked by underlining, SDS) are used in order to express the adversative meaning; these frame grammatically dubious, hard to understand negative constructions (double underlining), and their negated content (italics) is then neutralized by the final clause. This makes part of the Quechua sentence, as can be seen in my translation, virtually incomprehensible. Whilst it may not reflect the translators' lack of Quechua knowledge, it certainly shows their own confusion.

Thus the argumentation and rhetorical presentation lacks the theological explanations found in some of the Mesoamerican catechisms; in the Andean texts the authors limit themselves to repeating the unity of the Trinity using the above-mentioned devices as well as by negating multiplicity through linguistic means denoting exclusion and negation.

The fact that there are no complex theological explanations coincides with the authors' belief that the new religion has to be made easily understandable for the indigenous public (Tercero Cathecismo [1585] 1985, Proemio, fol. 4r, p. 355; Avendaño 1649, Prólogo al lector, p. 2). With respect to the life of the Andean people and comparisons with their experience, only sermon $\mathrm{V}$ of the Tercero Cathecismo refers to an Andean polytheism.

\section{3}

\section{Poetic expression}

We have seen that the Quechua doctrinal texts examined above use certain similar morphological items to express the unity of the threefold Christian god, such as huk, 'one', sapa, 'only, alone', the limitative suffix -lla and the expression kimsa persona, 'three persons'. They refrain from more figurative expressions, as does the only Franciscan song about the Trinity (Oré [1598] 1992, Primer cantico, fol. 69v-72r; fol. $71 \mathrm{r}$, verses 15 and 16 , transl. SDS):

23 Mana-m \{not-witness assertative\} maycannin-pa \{which of them-possessive genitive case\} persona-m \{person-witness assertative\} hucnim-pa the one/the other-possessive genitive case\} persona-n-chu \{person-3rd poss.-neg. when preceded by mana- element\}. 
Diosmi Dios Yaya,

Churipas Diostacmi.

quiquin Diospunim Spiritu sanctopas:

chaypas quimçantin,

manam quimça Dioschu

huc çapay Diosllam. ${ }^{24}$

Apum $^{25}$ Dios Yaya,

Churipas capacmi,

Spiritu sancto, apu capactacmi:

ychaca manam(,) cay quimça capacchu, huc apu Diosllam.
God is God Father, and the Son is also God.

And certainly God himself is also the Holy Spirit:

Thus they are three together, they are not three Gods, only one single God.

The Lord is God Father, he is also the Son, powerful And the Holy Spirit, he is the Lord, powerful:

But they are not three powerful ones

Lord God is only one.

This cántico is clearly written in repetitive sentences so as to make it easy to memorize, drawing on Western as well as Andean oral patterns. These songs were sung regularly and, possibly due to the rhythm and setting to Gregorian chant, seem to have been quite popular (Tibesar 1953: 81).

Another example of a poetic text, in this case a sermon, which not only has a rhythmic pattern but also intertwines the Christian belief in the Trinity with images of Andean flowers as well as the sun, moon and warmth, is the one Guaman Poma 'quotes' as being from Cristóbal de Molina. Here is a passage (transl. SDS): ${ }^{26}$

$\begin{array}{ll}\text { quimzantin } & \text { the three together } \\ \text { zapamanta runa } & \text { from one person } \\ \text { cayninpi suclla dios } & \text { in this being only one God } \\ \text { citoc } & \text { shining } \\ \text { llaurac } & \text { burning } \\ \text { canchac } & \text { brightening } \\ \text { trinidad cayninpi } & \text { in the being of the Trinity }\end{array}$

${ }^{24}$ It is convenient that Quechua does not use the copula 'to be' in the third person; therefore it does not have to make explicit whether a singular or plural entity is spoken of.

25 Although apu refers to the highest mountain spirit/deity in the Andean belief system, the translation of 'God' as apu was common, as the word was also used as a honorific. The same can be said about qapaq, a 'royal' title the Inca carried and which was in regular use for the Christian God's attribute of power (see, for example, the Paternoster and Ave María in the 1584 Doctrina Christiana [1985, fol. 1r-2r]).

${ }^{26}$ Guaman Poma ([ca. 1615] 2001, 625-626); for an analysis see Dedenbach-Salazar Sáenz (2013: 154-158). 
Both texts make use of parallelizing syntactic structures and semantic couplets/triplets to highlight the particular register and meaning. These poetic devices are found in the Biblical tradition (psalms) as well as in the Andes and were therefore a good choice to interpret the Christian faith: orthodox on the one hand, and, on the other, they would also have been familiar to the Andean people. Therefore it is easy to imagine that these songs may have influenced people's belief in the Christian God more than the sermons (of which we don't know how and when they were preached).

\subsection{The visual media}

The Andean people were not only exposed to indoctrination in the form of words, but visual media were also used to familiarize the new Christians with the contents of the faith. Today there are still some paintings as well as book illustrations left from colonial times. We can suppose that the indigenous population probably had access to paintings in churches ${ }^{27}$ rather than books and their illustrations.

There are different forms of depicting the Trinity. The most frequent one seems to be the image of three identical men, all very well clothed and carrying scepter and crown, accompanied by the Virgin, other persons or little angels (Ill. 2). Then there is a presentation of the Trinity as a person who has a head with three faces (Ill. $3^{28}$ ). And

${ }^{27}$ In her study of the paintings in the colonial Southern Peruvian church of Andahuaylillas Cohen Suarez (2013) presents the interrelation colonial images had with Christianisation texts and performances, such as comedias and autos (cf. Pazos 1951 and Trexler 1984). This shows that the indigenous population was exposed to several types of media which aimed at converting them by addressing different senses. Also see Andrews (2005) for a discussion of the different representations of the Trinity.

28 This painting is not dated except for the vague indication that it is from the 18th century, and it has to be observed that the trifacial Trinity, the history of which Pacheco traces back to the 13th century (see below), is found in the Andes mainly in the 18th century, and I have only found one which is dated in the 17th century (PESSCA [s.a.],

http://colonialart.org/archives/subjects/holy-trinity/figurative/synthetic/trifacial\#c454a$\underline{1599 b)}$.

However, the belief in multiple deities goes back to the Indian subcontinent of the third millenium before Christ, and representations of them became frequent in many ancient cultures. Stone sculptures in early medieval churches show the Trinity as three persons or as one with three faces. And whilst there is some discussion as to the Christian character of the earliest representations of a Trinity, these can definitely be traced back to the 12th century and became more abundant from the 14th century onwards. (Germán de Pamplona 1970, 1- 
finally there is, in the books of the Doctrina Christiana (Ill. 4), the criollo priest Oré (Ill. 5) and the native Andean chronicler Guaman Poma (Ill. 6), a Trinity which consists of three different persons: God the Father presented as a venerable old man, Christ with the cross, both sitting down, and above them a dove to represent the Holy Spirit. ${ }^{29}$

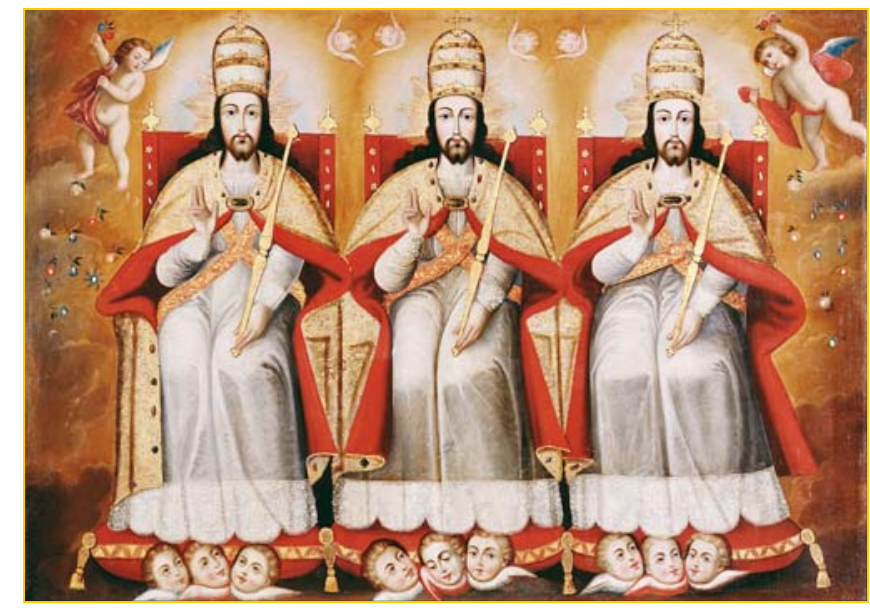

Illustration 2: Anonymous Cuzqueño: La Trinidad entronizada como tres figuras iguales (ca. 1720-1740), in the Museo de Arte de Lima

64). In Spain paintings similar to the trifacial Trinities known from the Andes can be found since the 16th century (ibid., figures 23-26).

Thus there were earlier representations of this motif, but we do not know since when they were brought to Peru or created in the Andes.

29 Another painting from 16th century Spain shows a large seated God Father with a dove in front of his chest and a very small crucified Jesus in his hands and lap; yet another one depicts a seated God Father holding the dead Jesus in his arms and a dove hovering in the left upper corner of the painting (Catalèg d'escultura i pintura 1996, no. 237, p. 282 and no. 238 , p. 283). This shows the great variety of depictions which were in circulation from the 15th to the 18th centuries (cf. Germán de Pamplona 1970, passim). 


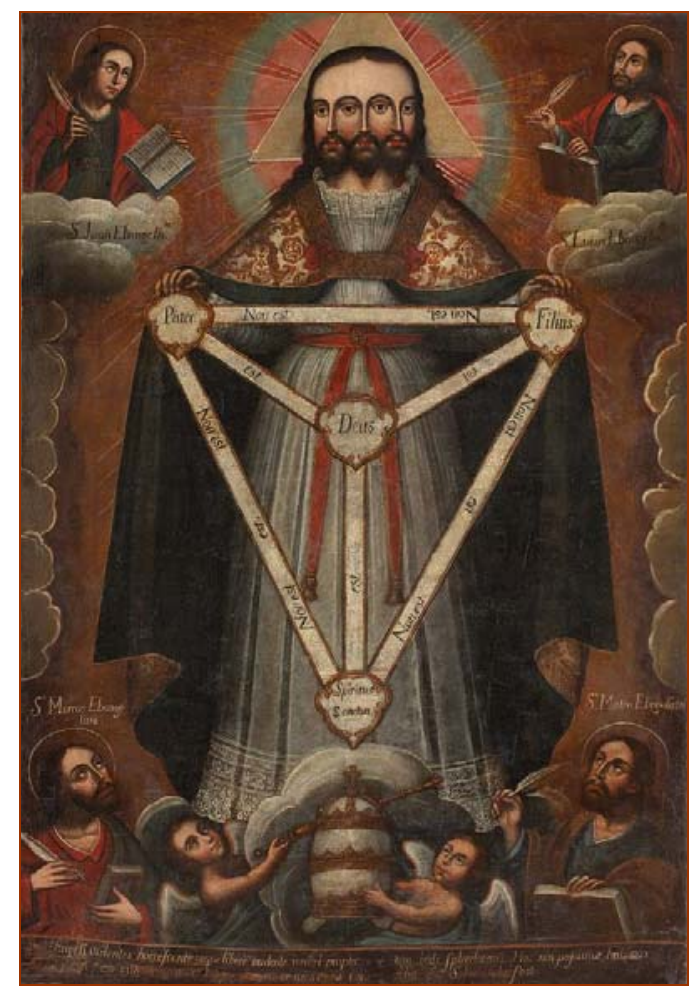

Illustration 3: Anonymous Cuzqueño:

Trinidad trifacial (ca. 1750-1770), in the Museo de Arte de Lima

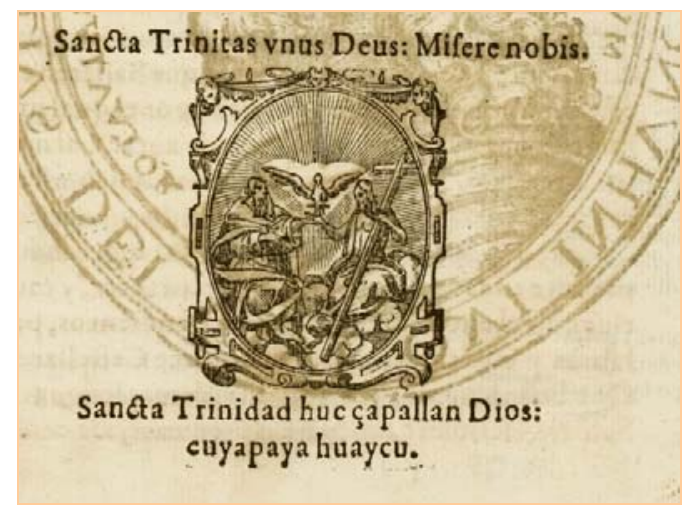

Illustration 4: Sancta Trinidad, in Oré: Symbolo catholico indiano (1598: fol. 66r [sic: bound behind fol. 70]) ${ }^{30}$

30 Identical with the left-hand illustration (of two) in the Doctrina Christiana ([1584] 1985, fol. $18 \mathrm{r})$. 


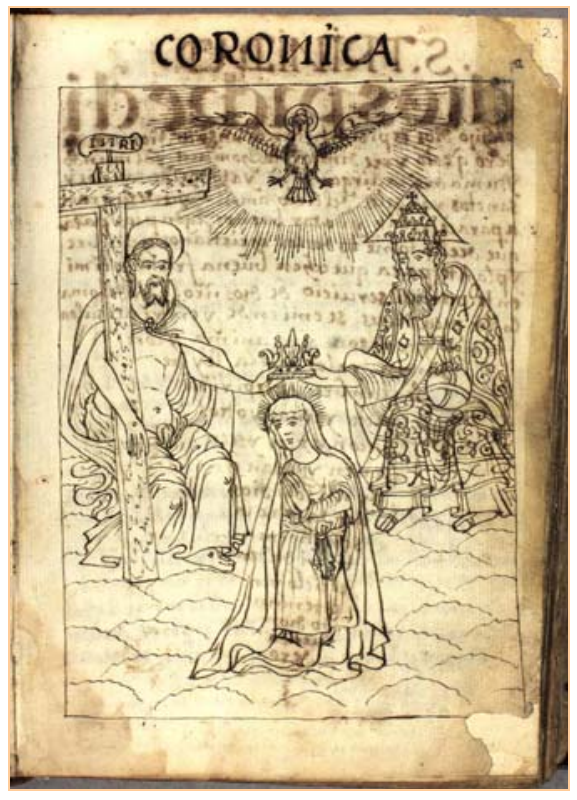

Illustration 5: Santísima Trinidad, in Guaman Poma de Ayala ([ca. 1615] 2001: 2)

When looking at the 17th century painter Francisco Pacheco's description of how the Trinity is and should be depicted, it becomes evident that the above-mentioned types of the Trinity seem to be representative.

..., el P. Martín de Roa reprehende una imagen dél [del misterio de la Santísima Trinidad], en que se representa un hombre con tres rostros, o cabezas, de la manera de Jano o Gerión, con que se escandaliza la gente cuerda y hace errar a los ignorantes. Pero, Juan Molano la afea muncho más, llamando a esta pintura "ficción diabólica", y cuenta que se apareció el demonio en esta forma a un santo religioso, año de 1221, asegurándole que era la Santísima Trinidad, mas, él, con luz del cielo, reconoció el engaño y, maldiciéndolo, lo echó de sí ....

Otra pintura deste misterio es poner tres figuras sentadas con un traje $y$ edad, con coronas en las cabezas y cetros en las manos, con que se pretende manifestar la igualdad y distinción de las Divinas Personas. Y parece que está favorecida esta imagen en la aparición de los ángeles en forma de peregrinos al santo Patriarca Abrahám, cuando, viendo tres, adoró uno sólo; y aunque la admite el P. Martín de Roa por sinificar la Divinidad solamente, todavía me parece que no satisface del todo a los ignorantes, pues necesita de particular señal de atributo en que se conosca cada persona, y de la colocación de los lugares, y si ha de estar el Espíritu Santo en medio.

También se pinta el padre Eterno sentado como venerable anciano, que tiene delante de si a Cristo, nuestro Señor, crucificado y muerto, puestas las manos en los brazos de la Cruz, ... y el Espíritu Santo sobre la cabeza, o en el pecho, en forma de paloma. Y, tal vez, se suele figurar la sacrosanta persona del Padre con tiara y traje de Pontífice sumo, sentado sobre nubes y, en una sábana blanca, tiene a su soberano Hijo muerto, como cuando lo baxaron de la Cruz, con sus 
cardenales y llagas, y la tercera persona en figura de paloma, y ángeles con los instrumentos de la pasión. Los cuales dos modos parecen decentes a la pintura deste misterio. Así lo vemos en estampa de Alberto Durero. ...

... que es fuerza que se represente Dios conforme se ha aparecido en el Viejo y Nuevo Testamento; y tiene muncha razón, porque habiendo de pintar a su Majestad no le podemos pintar mejor que como se pintó El mismo en la Sagrada Escritura.

Conforme a esto, la más recebida pintura dela Santísima Trinidad ha de ser pintar al Padre Eterno en figura de un grave y hermoso anciano, no calvo, antes con cabello largo y venerable barba, y uno y otro blanquísimo, sentado con gran majestad, como se apareció a Daniel, profeta, con alba que tenga los claros blancos y los oscuros columbinos, y manto de brocado, o de otro color grave, como la túnica de azul claro, y el mando de morado alegre; y, a su mano derecha, sentado, Cristo nuestro Señor, como lo dice David y lo afirma la Santa Iglesia en el Credo (aunque los doctos saben cómo se ha de entender en Dios esto de la mano derecha, en la pintura se ha executar [sic] como suena). Píntese de 33 años de edad, con hermosísimo rostro y bellísimo desnudo, con sus llagas en manos, pies y costado, con manto roxo, arrimado a la cruz, o que ambos sostienen el mundo y bendicen los hombres; y en lo alto, en medio, el Espíritu Santo en forma de paloma ....... Acompañése este misterio con resplandores, ángeles y serafines que asisten con admiración y respeto. Yo añado a toda esta pintura una luz que sale del pecho del Padre Eterno, y otra del pecho del Salvador, que paran en el Espíritu Santo, para sinificar que procede de ambas Personas. Púedese, a la redonda, hacer un círculo perfeto de resplandor, que denota que Dios no tiene principio ni fin. El triángulo formado de tres lineas iguales que se pone por diadema en la cabeza de Dios Padre (a diferencia de las potencias de Cristo) es también símbolo de la Santísima Trinidad, como lo aplicó, ingeniosamente, el Maestro Francisco de Medina en su mismo epitafio. (Pacheco [1638] 1956, fol. 495-497, p. 195-198; italics by SDS.)

Thus, according to Pacheco the most desirable depiction is the one with the Father, the Son and the Dove. Most dangerous is, according to the author, the presentation of a head with three faces, which in one instance was even seen as a "diabolic fiction". ${ }^{31}$

It is interesting that the indigenous author Guaman Poma presents the canonical Trinity suggested by Pacheco. ${ }^{32}$ In the churches all types of Trinity depictions were found. ${ }^{33}$

Whilst the indigenous population must have been confused because of different ways of describing the Trinity orally, the variety of its depiction in paintings may well have

31 According to the Catalèg d'escultura i pintura (1996, 391), Pope Urban VIII prohibited this representation in 1628 .

32 Guaman Poma (cf. Ill. 5) also paints the triangle on God Father's head as described by Pacheco.

33 See PESSCA ([s.a.]), Holy Trinity (at: http://colonialart.org/archives). 
added to this confusion: which image may someone have had of the new god if it was sometimes shown as a head with three faces, at other times as three identical persons, and yet again as two persons and a pigeon. ${ }^{34}$ On the other hand, Andean deities changed their features and appearance as well, so that the variety of showing the Christian threefold god may not have been all that extraordinary an idea for them. It is possible, however, that somebody having grown up in a polytheistic religion might have thought that every different presentation of the Christian god showed a different deity. And thinking of those who did receive a certain schooling and were more familiarized with Christian concepts (chroniclers such as Guaman Poma or Pachacuti Yamqui), they may well have thought that the Christian Spaniards were a rather confused lot themselves who didn't really know who their own god was!

\section{The multiplicity of Andean deities in the prehispanic era}

\subsection{The Andean context}

In order to shed light on Andean concepts of multiple deities which may have had influence on how the native population interpreted the Christian Trinity, it is necessary to have a look at the Andean pantheon of the time. I will limit myself to a brief description of some of its basic features. When trying to reconstruct this we have to be, however, conscious that the information on these matters is almost always filtered through the eyes and minds of the Spanish chroniclers and priests. Also, there were obviously regional differences as well as different forms of belief among the people on the one hand and the Inca elite on the other.

A very brief glance at the Andean pantheon first: the basic principle of life - and more than a "goddess" - was, and still is, Pachamama, World Mother. Then there was a series of numinous beings, many of whom were manifest in the highest mountain peaks, which were generically called $a p u$, a term which in Quechua means 'rich' and 'powerful'. Just like Pachamama, these numinous beings are still being adored in the present. They could also manifest themselves in rocks or stones or other natural objects, or in manmade figures. They all were called waka in Quechua, a term which implies something 'special' and may come close to our concept of 'holy'. ${ }^{35}$

${ }^{34}$ For ambiguities and possible misunderstandings of Christian images see Valenzuela Márquez (2006: 499-503) and Dedenbach-Salazar Sáenz (2013: 187-189).

35 For a detailed description of the manifestation of waka in the colonial period see the extirpator of idolatries Arriaga's work (Arriaga [1621] 1968, cap. II, p. 201-205). 
The Incas also adored several deities, although the Sun came to play the most important role in their faith. The Inca ruler himself was conceived of as the 'son of the Sun' and his wife was related to the Moon. Another deity adored by the Incas was Viracocha, whose characteristics are still not completely understood. Besides what we might call a state cult the Incas allowed other regional gods to be venerated, and, depending on the influence ascribed to them, they themselves adored them as well, which was, for example, the case with the powerful coastal waka Pachacamac. ${ }^{36}$

\subsection{Information in the chronicles}

It will be interesting to see if there were deities with multiple characteristics in the Andes, so as to find out about possible parallels which offered themselves to the indigenous people when they were taught about the Christian Trinity. Although there are not many numinous beings with multiple character, they are mentioned in different types of ethnohistorical sources.

Acosta, a Jesuit chronicler and responsible for the Third Lima Council texts, who wrote in 1590 (1954, libro V, cap. XXVIII, p. 174-175), tells us the following:

Y cierto es de notar que en su modo el demonio haya también en la idolatría introducido trinidad, porque las tres estatuas del sol se intitulaban Apointi, Churiinti y Inticuaoquí, que quiere decir el padre y señor sol, el hijo sol, el hermano sol, y de la misma manera nombraban las tres estatuas del Chuquiilla, que es el dios que preside en la región del aire donde truena y llueve y nieva.

Acuérdome que, estando en Chuquisaca [Sucre, Bolivia], me mostró un sacerdote honrado una información, que yo la tuve harto tiempo en mi poder, en que había averiguado de cierta guaca o adoratorio, donde los indios profesaban adorar a Tangatanga, que era un ídolo, que decían que en uno eran tres, y en tres uno; y admirándose aquel sacerdote de esto, creo, le dije, que el demonio todo cuanto podía hurtar de la verdad para sus mentiras y engaños, lo hacía con aquella infernal y porfiada soberbia con que siempre apetece ser como Dios.

Here, and even more so in the title of the chapter - "cómo el demonio quiso también imitar el misterio de la Santísima Trinidad" - it becomes apparent that the Christian priests saw the multiplicity of the Andean gods as the work of the devil. This is in agreement with Polo de Ondegardo's observation that the native 'witches' say that the indigenous people should not adore the Trinity ([1585] 1985, cap. VI, fol. 5v) - these

36 See Gareis (1987) for state and regional cults and priests; see the Tradiciones de Huarochirí ([ca. 1608] 1991, ch. 22, 23) for the adoration of Pachacamac by the Incas. 
native priests were seen as sent by the devil (Tercero Cathecismo [1585] 1985, fol. 109r).

It is possible that the aforementioned god is the same as that represented in a stone from the area of Cochabamba in Bolivia (Ill. 6).

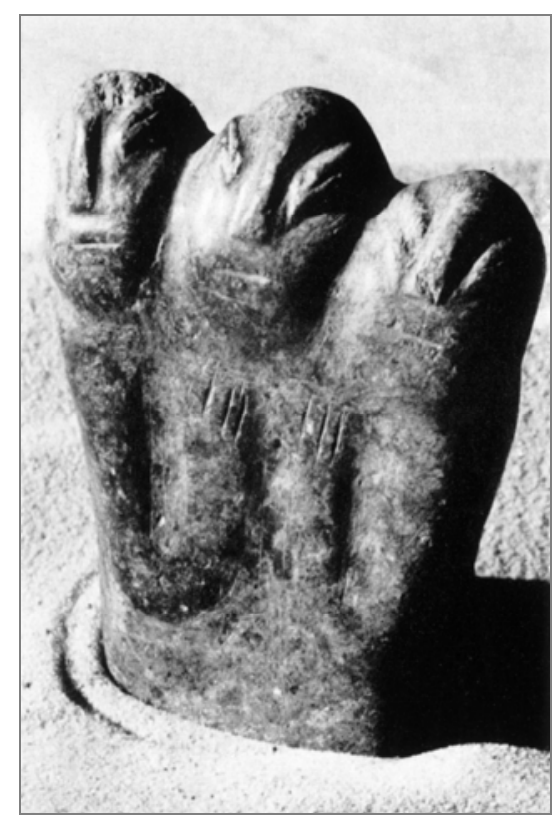

Illustration 6: A threefold deity in stone (from excavations in Cliza, Dep. Cochabamba, Bolivia, Cultura de los Túmulos, ca. 500 BC - Class. Tiahuanaco) (Archaeological-ethnographic collection [BASA] of the Department for the Anthropology of the Americas, Bonn University; acquired in 1956; information BASA record)

Thus the Jesuit Torres Vázquez says that, at the beginning of the 17th century, he saw a similar figure on the island Alnapia (Anapia today) in Lake Titicaca:

En esta [isla] se hallo en tiempos pasados un idolo muy bien labrado con tres cabezas aquien los indios adoraban diciendo que aunque era un Dios encerraba en si tres rudo bosquexo del misterio inefable de la Santisima Trinidad un Dios y tres personas. Este idolo se dice que enviaron antiguamente los Españoles a España por cosa maravillosa. ${ }^{37}$

It is interesting that Torres does not see the devil at work in this figure, but a form, although imperfect, of the Christian Trinity, whereas Garcilaso thought that the indigenous people conceptualised the native threefold god as Trinity in order to appear Christians ([1609] 1960, vol. 2, libro II, cap. V, p. 49). ${ }^{38}$

37 In Barraza $(1937,199)$. Other chroniclers - all later - also comment on these deities (Ramos Gavilán [1621] 1988, [libro primero], cap. XXIV, p. 149; Calancha [1639] 1972, vol. 1, parte segunda, libro primero, cap. II, p. 121).

38 Cf. Mills (2007) for a discussion of Andean continuities in colonial religion. 
The indigenous chronicler Felipe Guaman Poma de Ayala ([ca. 1615] 2001, 5

5-56) talks, when presenting the ancient period of the second age of the world, the "vari rvna ... segunda edad" (ibid., p. 54), of a deity of three (four) persons:

tenian los yndios antiguos

conocimiento de que abia un solo dios tres personas desto decia aci que el padre era justiciero - yayan runa muchochic - el hijo caritatibo churin runa cuyapayac - el menor hijo que daua y aumentaua salud y daua de comer y enbiaua agua del cielo para darnos de comer y sustento - sulca churin causaycoc micoycoc runap alinninpac al primero le llamaua yayan yllapa al segundo chaupi churin yllapa al quarto [sic] le llamaua sullca churin yllapa questos dichos tres personas eran y creyyan que en el cielo era tan gran magestad y señor del cielo y de la tierra y aci le llamauan yllapa y despues por ello los yngas sacrificaron al rrayo y temieron muy mucho ... the Indians of the old times had knowledge that there was only one god three persons, of whom the following was said: that the father was very just - yayan runa muchochic [their father who punishes people] - the son was charitable - churin runa cuyapayac [his son was a great lover of the people] - the younger son who gave and increased health and provided food and sent water from the sky so as to give us food and sustenance sulca churin causayoc micoycoc runap alinninpac [his youngest child who has life, who has food for the wellbeing of the people]. The first one was called yayan illapa [their father Yllapa], the second chaupi churin yllapa [his middle child Yllapa], the fourth [sic] was called sullca churin yllapa [his youngest child Yllapa], that these mentioned three persons existed; and they believed that in heaven he was a very great majesty and lord of heaven and of the earth and so they called him Yllapa and later because of this the Incas sacrificed to the lightning and were very much afraid [of him] ... (translation SDS).

It can clearly be seen that Guaman Poma tries to give the Andean deity Illapa (who is the god of thunder and lightning) a Christian appearance. The qualities of the three persons of Illapa are justice, charity and the provision of wellbeing and fertility to the people. Whilst the first two attributes are also Christian, the third one is typically Andean. The Trinity is here manifest in a father and his two sons, of whom one is the 
middle and the other the youngest one. ${ }^{39}$ It is interesting to see how Guaman Poma makes a mistake when mentioning four persons, but identifying only three. The fact that there is no eldest son, but only a middle and a youngest as well as the mentioned mistake of counting one - two - four, may mean that this deity really existed (Illapa is also documented in other sources), but maybe it consisted of four and not of three individuals and Guaman Poma omitted one in order to fit the deity into the Christian Trinity concept. ${ }^{40}$

Another chronicler, of partly indigenous extraction, Garcilaso de la Vega ([1609] 2002, libro II, cap. [X]XVII, fol. 52v-53r), mentions a similar phenomenon ${ }^{41}$ in the context of Inca poetic forms and referring to Blas Valera (a mestizo priest and chronicler whose writings are only preserved as quotations in Garcilaso). He tells about a narrative in which a man is in charge of thunder and lightning, whilst his sister is responsible for hail, rain and snow: ${ }^{42}$

los Incas poetas los compusieron, filosofando las causas segundas que Dios puso en la region del ayre, para los truenos, relampagos, y rayos, y para el granizar, neuar, y llouer todo lo qual dan a entender en los versos, como se verá. Hizieronlos conforme a vna fabula que tuuuieron [sic], que es la que se sigue. Dizen que el hazedor puso en el cielo vna donzella hija de vn Rey, que tiene vn cantaro lleno de agua, para derramarla quando la tierra la ha menester, y que vn hermano della lo quiebra a sus tiempos, y que del golpe se causan los truenos, relampagos, y rayos. Dizen que el hombre los causa, porque son hechos de hombres feroces, y no de mugeres tiernas: dizen que el granizar, llouer, y neuar lo haze la donzella, porque son hechos de mas suauidad y blandura, y de tanto prouecho.

39 González Holguín ([1608] 1989, 99): "Chaupimitta viñak o chaupiruna. Hombre hecho, ni moço, ni viejo de mediana edad", y "Sullcca. El minimo, o menor hijo, o hermano" ([1608] 1989, 331).

40 Some authors ascribe the supposed Andean Trinity to the (Christian) devil and his work. Thus the Christian author of the Relación de la religión y ritos del Perú hecha por los padres agustinos ([1561?], fol. 3v; 1992, 10-11) sees the threefold god of Huamachuco, northern Peru, as a 'completely false Trinity' by (cf. Acosta above). Others try to make the prehispanic Andeans Christians by supposing their native monotheism (Guaman Poma).

41 For Garcilaso the mutliple Illapa is not a deity, but a servant of the Sun ("criados del sol" [1609] 1960, vol. 2, libro II, cap. XXII, p. 74; 1960, vol. 2, libro III, cap. XXI, p. 114), put in the sky by the creator ("el Hacedor puso en el cielo" - 1960, vol. 2, libro II, cap. XXVII, p. 79). This is a logical consequence of Garcilaso's argumentation that before the Spaniards came the Incas had knowledge of one god (1960, vol. 2, libro II, cap. II, p. 43-45).

42 This multiple array of functions one individual supernatural being can have can also be found in contemporary stories (Ortiz Rescaniere 1980, 81-82). 
Garcilaso presents a Quechua text, with a translation into Latin, supposedly created by Blas Valera, as well as Garcilaso's own translation into Spanish (ibid., fol. 53v). Here follows the text (with my own translation ${ }^{43}$ ):

$\begin{array}{lll}1 & \text { Cumac [sic: Çumac] Nústa } & \text { Beautiful royal virgin, } \\ 2 & \text { Toralláyquim } & \text { your little brother }- \\ 3 & \text { Puyñuyquita } & \text { your jar, } \\ 4 & \text { Paquircayan } & \text { he has just broken it. } \\ 5 & \text { Hinamantara[c] } & \text { Thus } \\ 6 & \text { Cunuñunun, } & \text { it / he thunders } \\ 7 & \text { Yllapántac. } & \text { and it / he flashes with lightning and } \\ & & \text { thunders. } \\ 8 & \text { Camri Nústa, } & \text { And you, royal virgin, } \\ 9 & \text { Vnuyquita } & \text { your water } \\ 10 & \text { Paramúnqui } & \text { you [let it] rain here. } \\ 11 & \text { Mayñimpiri } & \text { And wherever it is, } \\ 12 & \text { Chichimúnqui, } & \text { you [let it] hail here, } \\ 13 & \text { Ritimúnqui. } & \text { you [let it] snow here. } \\ 14 & \text { Pacha rúrac, } & \text { Maker of the world, } \\ 15 & \text { Pacha cámac, } & \text { Animator of the world, } \\ 16 & \text { Viracocha, } & \text { Viracocha, } \\ 17 & \text { Cay hinápac } & \text { so for this } \\ 18 & \text { Churasúnqui } & \text { he put you [here], } \\ 19 & \text { Camasúnqui. } & \text { he gave you life. }\end{array}$

This shows several characteristics which are typical of Andean verbal art, such as the modified repetitions (lines 6-7, 10-12-13, 14-15-16 y 18-19) and the parallelization of 1-3 with 8-9. Also, this kind of discourse, directing oneself to a second person, is present in other Andean prayers. ${ }^{44}$ There is a hierarchization of the princess as inferior to the Trinitarian Andean deity Pacharurac Pachacamac Viracocha. It is possible that this last part of the prayer was added in the early colonial period in order to adapt the concept to the Christian system (see note 41) - either by the indigenous author or by Blas Valera or Garcilaso.

Despite these possible colonial influences it can be noted that Acosta's and Guaman Poma's description of basically the same god is also found in Garcilaso: it is a multiple

43 I have used the 2002 Garcilaso facsimile edition so as to follow the original spelling of the Quechua text, but I have connected the separate syllables according to Quechua linguistic structure. The translation takes into consideration Garcilaso's own remarks on some of the words which precede the text itself. Cf. Garcilaso de la Vega [1609] 1960, vol. 2, libro II, cap. XXVII, pp. 79-80.

44 It also uses the CODM/VODM in lines 6, 7, 10, 12, 13 - see section 4.3 for an explanation. 
being that incorporates the elements of thunder and lightning as well as rain and water. It should be added that this deity is particularly Andean in that none of the chroniclers describes it explicitly as only good (or only bad), but that is has - in its own essence, that is in the three (four) in one - the destructive aspect of thunder and lightning (which must be the one Guaman Poma calls justice) as well as the benevolent trait of the fertilizing waters (which must be what Guaman Poma describes as charitable), and even in this latter element, water, both sides of the same coin are present: water can fertilize, but it can also destroy. Here we have a possible idea of the conceptualization of the multipersonality of Andean numinous beings: they are one in that they appear together and show combined effects, but they are distinct in that they can affect human life in different ways.

\subsection{The Huarochirí texts (ca. 1608)}

A source for Andean language and culture which does not proceed from the nucleus of the Inca empire and which is based on oral traditions of an ethnic group in the province of Lima are the so-called Huarochirí Traditions. Written down around 1600, they consist of myths and descriptions of rituals related to the myths. What is special about this source is that it is written entirely in Quechua and a discourse analysis shows that the central part of the narratives consist of original Andean traditions (cf. DedenbachSalazar Sáenz 1994, 2003).

I will now look at how the deities, and particularly those with a multiple character, are presented in these texts (cf. also Trimborn 1960).

The goddess Chaupinamca, for example, is said to have four sisters:

chaymantam canan cay chaupiñamcap ñañancuna ñiscanchicta villason / cay chaupiñamcas tucoyninmanta mayornin carcan / chaysaua ñañansi llacsahuato carcan / chaysaua yoricsi mirauato carcã / chaysauas vrpayhuachac sutioc carcan / cay hoquentam mana yachanchiccho / tucoyninca pichcas carcan /
Now we'll tell about Chaupiñamca's sisters whom we mentioned. It is said that this Chaupiñamca was the eldest of them all. Furthermore, it is said, there was her sister Llacsahuato. Furthermore, it is said, there was the one born [as] Mirahuato. Furthermore, it is said, there was the one with the name Urpayhuachac. About this other one we do not know. All together they were five, it is said. 
(Tradiciones de Huarochirí, ch. 10, fol. 76 v, transcr. and transl. SDS; cf. Salomon and Urioste eds. 1991, 78 [Engl. transl.], 182 [Quechua transcription]. ${ }^{45}$ )

checacunam ñincu chaupiñamcacta pihcas carcan ñispa / caycunap mayorninmi cotocha o paltacha sutioc / chaupiñamuca huc segunda ñañanmi copacha ñiscanchic llacsahuato sutioc / cay llasahuatus chillacopi tian / ... / chaymantam ampuche o ampuxi ñiscanchicri mirahuato sutioc carcan /
The Checa say of Chaupinamca: "She is said to be five". The eldest of these is called Cotocha or Paltacha. [Of] Chaupiñamuca, another, second sister is the one we call Copacha, with the name Llacsahuato. It is said that this Llacsahuato lives in Chillaco.... And then the one we call Ampuche or Ampuxi, her name was Mirahuato ...

(Tradiciones de Huarochirí, ch. 13, fol. 78r-v, transcr. and transl. SDS; cf. Salomon and Urioste eds. 1991, 85, 188-189.)

The intimate relationship among these sisters becomes evident when at the end it is said that Chaupiñamca is present in a five-armed stone: "cay chaupiñamcas canan pichca ricra rumi carcan chirayasca", 'this Chaupiñamca now, it is said, was a five-armed stone, she had become stone' (ibid., ch. 10, fol. 76v, transcr. and transl. SDS; cf. Salomon and Urioste eds. 1991, 76, 182).

This shows that the multiplicity of Andean deities, as it appears in the Huarochrí Traditions, can be based on kinship ties, in which it is similar to the Christian concept of the Trinity, but also an authentic Andean concept. ${ }^{46}$

Another case of a multiple deity is Pariacaca, the most powerful numinous being of Huarochirí. Pariacaca is said to be born from five eggs, in the form of five falcons.

cay ñiscanchiccunacta ña puchocaptinsi pariacaca ñiscaca pihca runtomanta
It is said that when he had already finished what we

45 I have not marked or transcribed words or syllables which were crossed out by the writer of the Quechua text as they are not relevant for my discussion.

46 However, the commentator-narrator has sometimes problems in explaining certain inconsistencies in the relationships among the deities: "huquinmi chaupiñamcacta pariacacap paninsi ñincu / hucmi tamtañamcap churinsi carca ñincu / ... / huaquinmi canan yntip churinsi ñincu / chay ynam mana hunanchaypaccho", "Some say of Chaupiñamca: "She is said to be Pariacaca's sister"; others say: "She is said to have been Tamtañamca's child". Now others say: "She is said to be the Sun's child". In that way nothing can be understood.' (Ch. 13, fol. 79v, transcr. and transl. SDS; cf. Salomon and Urioste eds. 1991, 87, 191.) 
pihca huaman pahyamurcan ${ }^{47}$ / chay pihca huamansi natac runamam tucuspa purirircan / chay pachas ... chay chay huchancunamantas piñaspa tamya hatarispa mamacochaman tucoy hinantin huasintahuan llamantahuan aparcan mana hucllactapas quispichispa / mentioned, the one called Pariacaca emerged from five eggs [as] five falcons. Those five falcons, already converted into a human being, started to walk around. Then, ..., as he became angry about all those sins, rising up [as] rain, he took them all together, with their houses and their llamas, to the sea, without saving even one.

(Tradiciones de Huarochirí, ch. 5, fol. 69v, transcr. and transl. SDS; cf. Salomon and Urioste eds. 1991, 59-60, 168.)

In Quechua, a particular grammatical construction is used to express this transformation, which is only used with deities. Adelaar has called this phenomenon "the complement of divine manifestation" (CODM) which is used in the following way: "in sentences where the subject position is occupied by the name of a god or a goddess, a noun phrase not followed by a Case affix can indicate the shape in which that god or goddess manifests himself or herself before the eyes of mankind." (Adelaar 1994, 118.)

In this construction the only verbs which occur are those that are limited in their usage to transformation processes, such as 'emerge', and the equation of Pariacaca as subject 1 with the five falcons as subject 2, without any other morphological marker such as 'as' or 'in form of'; the same happens with Pariacaca 'rising as rain': consequently in the Quechua text there is no equation marker used as I have done in the English translation.

Here the Andean god is a multiple deity and can take different shapes, one of which is not unlike the Christian dove - falcons. In linguistic terms, it can be noted that Quechua makes a limited usage of the plural, that is, once the plurality is established, one can go back to using the singular. This linguistic medium emphasizes the fluidity between a single and a multiple person because singular and plural forms are used indistinctly (marked with italics in the above quotation).

47 This verb has been translated in different ways. Taylor uses 'salir' (Tradiciones de Huarochirí 1987, 115), Trimborn 'entfliegen' ('fly away') (Tradiciones de Huarochirí 1967, 43) and Salomon and Urioste 'fly forth' (Tradiciones de Huarochirí 1991, 59). It is not present in the dictionaries and the translators seem to base themselves on the general sense of the sentence. Maybe the verb is onomatopoetic consisting of the syllable "pah" (perhaps related to or a regional variant of Cuzqueño phar, an onomatopoetic word for a bird's wingflapping, according to Lira 1945, 804) and the verbalizing suffix -ya, 'become'. 


\section{Divine multiplicity in the colonial context}

\subsection{Comparison of the linguistic devices used in Andean and Christian Quechua texts to describe divine multiplicity}

As has been seen so far, the Christian god manifests himself in three persons; the Andean deities also manifested themselves in different individuals related by kinship. Let us now compare the linguistic devices Andeans and Christians used in Quechua for explaining a multiple deity.

In order to express this multiplicity, the verb of divine manifestation (VODM), tuku-, 'to become', is used in the Huarochirí texts: [Pariacaca says to Huatyacuri:] "ri chay huc horcoman / chaypim huanaco tucospa huañusca siriconqui / ... / chaymi camca runa tucospa ancha nanacta caparispa pauarimunqui“", "Go to that other mountain; there, transforming yourself [into] a guanaco, you will stretch out [as if] dead. ... Then you, transforming yourself [into] a human being, starting to shout strongly, you will start running here.' (Tradiciones de Huarochirí, ch. 5, fol. 68v, transcr. and transl. SDS; cf. Salomon and Urioste eds. 1991, 58, 166). With reference to Chaupiñamca it is said: "chaysi tuylla pachampitac rumi tucorcan / chay rumis canancamapas himanam runap chancan hina chancayoc racayoc tian", "Then, it is said, [the woman] transformed herself [into] stone. That stone is even until now sitting there having thighs and a vagina like the thighs of a human being.' (Tradiciones de Huarochirí, ch. 5, fol. 69v, transcr. and transl. SDS; cf. Salomon and Urioste eds. 1991, 59, 168.)

In a similar way the Christian Doctrina ([1584] 1985, fol. 4r/5r) texts express that "Nuestro señor Iesu Christo, en quanto hombre fue concebido por Spiritu Sancto." This reads in Quechua: "Iesu Christo Dios apunchicmi Spiritu sanctomanta runa tucurcan", 'Our Lord Jesus Christ transformed himself from the Holy Spirit [into] a human being.'

It seems that here the translator uses the CODM/VODM construction and we can easily imagine what kind of association this way of expressing the Trinity may have evoked in the indigenous people's minds. The following passage offers an interpretation in Andean terms as well: "Agora has de entender, que el hijo de Dios, que se llama Iesv Christo, se hizo hombre nasciendo de la virgen Maria"; in Quechua: "Caytahuampas yachaytac. Cay capac Diospa churin Iesu Christo sutiocmi viñay virgen Sancta Mariap vicçanpi runa tucurcan, paymantatac pacarimurcan ${ }^{48 "}$ (ibid., fol. 20r). "And also this you have to understand: This powerful son of God, called Jesus Christ, transformed

48 As I have shown elsewhere (Dedenbach-Salazar Sáenz 1997, 199) the word paqari-, used here for the birth of Jesus, was also used for the birth of Andean deities (Tradiciones de Huarochirí ca. 1608, ch. 1). 
himself [into] a human being in the eternal Saint Mary's womb, and from her he emerged to us.'

The parallel between the Andean and the Christian expression chosen for the divine transformation is impressive. It makes it seem quite probable that the presentation of the Christian Trinity, with its emphasis on the multiplicity and at the same time the unity of God, by means of well known linguistic devices, made it possible for the indigenous people not only to find parallels between both traditions, but also to include the multiple Christian god into their own Andean pantheon.

\subsection{An instance of colonial native understanding of the Christian Trinity}

The colonial period is characterized by the influence both ideological systems had on the cultural manifestations of the indigenous population. Unfortunately there are almost no sources to show how the Andean people managed the multiplicity of their own gods and the Trinity of the Christian god (however, Guaman Poma's explanation of Illapa as three or four individuals - mentioned above - is an instance of such ambiguous, colonial interpretation). Let us look at one of these rare documents.

In a lawsuit from 1662 about idolatrous practices, Sebastian the Elder, from a village in Chancay (on the central coast of Peru) is asked about the concept of the Christian god:

Y preguntandole que quien es Dios = Dixo que el Hijo y el Espiritu Sancto, y que el Hijo solo es Dios $=$ Y preguntandole que como no decia que el padre era Dios $=$ Dixo que el Padre y el Hijo era Dios, y el Espiritu Santo era Dios para el cielo $=\mathrm{Y}$ preguntandole que qual de las tres Diuinas personas bajo a redimirnos $=$ Dixo que el Hijo bajo a redimirnos $=$ Y preguntandole que qual de las tres Diuinas Personas se hiço hombre en las entrañas de la Virgen Sancta Maria = Dixo que el Hijo se hiço hombre $=$ Y preguntandole que como se hiço hombre $=$ Dixo que como Dios se hiço hombre $=$ Y preguntandole que si se hiço hombre por obra de varon $=$ Dixo que se hiço hombre como qualquiera de nosotros engendramos $=\mathrm{Y}$ preguntandole que quien habia muerto por el hombre dixo que el Hijo de Dios = Y preguntandole que si auia muerto en quanto Dios o en quanto hombre $=$ Dixo que auia muerto en (f.36) quanto Dios = Y preguntandole que si la Sançta [sic] Madre Yglesia Catholica era Dios = Dixo que era Dios la Sancta Madre Yglesia Catholica ... (Visita a la doctrina de Sayán, Declaracion de Sebastián de Quito el viejo [1662] 1991, 102-103).

The answers of the old man show that he does have an idea of the Christian doctrine, but he is quite confused about a number of things. So the Holy Spirit for him is the "god of heaven" and the Church itself is God; God died in his quality of being God, not of being human. This confusion shows that the concept of the multiplicity of the Christian 
god was not conveyed adequately. ${ }^{49}$ In this case, the man seems to understand that God is a plurality, and yet he is not sure about its characteristics and assigns a clear identity to one of the triune elements.

\section{Modern Andean concepts of the Trinity}

It has become evident that the Andean pantheon and conceptualization of the divine was not completely different from the Christian concept of a multiple god. However, in Andean narratives collected in the 20th century, we find a new and different interpretation of the Christian god: they construct a chronological periodization from the era of the Father, through the Son Jesus Christ, to the Holy Spirit. ${ }^{50}$ In this way the Trinity changes its dimension: instead of a simultaneous existence of the three persons who form one and the same god, we find one of these persons after the other, characterizing the passage of time. That this conceptualization has its origin in Spanish colonial efforts to teach the Trinity is clear from what Alonso de la Peña Montenegro observed at the end of the 17th century: "Quando les explican el Misterio de la Santissima Trinidad, diziendo, que ay Dios Padre, Dios Hijo, y Dios Espiritu Santo, acomodan luego la generacion Divina a las humanas, y creen que el Padre es mas antiguo que el Hijo, y que siendo tres personas distintas, estan en tres lugares distintos, apartados, y divididos entre si, ..." (Itinerario para parochos de indios 1678, lib. II, tract. III, session IV, p. 329).

The editors of the 20th century Quechua text collection Kay Pacha present five periods for the village Pinchimuro (Prov. de Quispicanchis, Dep. del Cuzco), starting with primordial time and creation; this is followed by the so-called gentiles or ñawpaq machulas, that is the ancestors; the time of the Incas and the conquest; the modern period (of the haciendas including independence); and finally the future. The first two eras correspond to Dios Yaya (God Father), the following two to Dios Churi (God Son)

49 Arriaga ([1621] 1968, cap. VII, 219) clearly describes and analyzes the problems Christian teaching faced, such as some priests' lack of preparation and knowledge of the indigenous language.

${ }^{50}$ It is, of course, difficult to know when this idea came into Andean religious beliefs because there are virtually no texts of indigenous tradition after Huarochirí and Guaman Poma (i.e. the beginning of the 17th century) until the collection of texts by anthropologists in the 20th century. 
and the last one to the Holy Spirit. These eras are interrelated in that one proceeds from the other and is based on the previous one. ${ }^{51}$

We do not exactly know the origin of this transmission of the temporal concept of the synchronic Trinity into a diachronic temporal dimension, and it has been suggested that it may be based on Joachim of Fiore's ideas (Gioacchino da Fiore) (Urbano 1993, 284). Joachim, who lived in the 12th century, interpreted the events narrated in the Old Testament projecting them onto those found in the New Testament and onto the future. Moreover he correlated this concept of history with the Trinitarian idea in interpreting human history as three "status", which in turn he correlated to God, the Son and the Holy Spirit. However, the three "status" were not three eras following upon each other, but an interrelation of the three Trinitarian elements. (Mehlmann 1991, 85-89, Lerner 1988.) However, his ideas were interpreted in different ways from what he had intended and turned into chiliastic or millenarist concepts which consisted in the expectation of a peaceful final and millenarian empire of the Spirit. ${ }^{52}$ This millenarist concept gained increasing influence in the 16th century; especially in the New World the Franciscans' ideas that the conversion of the Indians implied the beginning of a new millenium. (Konrad 1981, 737.)

It has been shown (Saranyana and Zaballa 1992, especially ch. III) that Joachim was well known in Mexico because of the diffusion (and particular interpretation) of his ideas by the Franciscans, but also in Cuzco where the authors document a canvas in which Joachim himself figures as an iconographic element. There have been many Franciscan convents in Peru over the centuries, but whilst it is possible to reconstruct their physical presence, it is much more difficult to capture the particular ideology they may have spread to the native population. ${ }^{53}$ Thus we do not know how the concept of

51 Documented in Marzal $(1971,62)$ and Gow and Condori eds. (1976, 20-34); cf. Phuturi Suni (1997, 268-96, 282-283). Urbano (1980, 111-119) discusses how what in Christianity is a Trinitarian concept, has developed into three separate deities in the Andes, each related to a different era. Whilst the meaning of the Andean concepts yaya ('father') and churi ('son') could be related to the first two elements, espíritu did not seem to have an easily available equivalent in the Andes (Urbano 1980, 123-124).

52 These ideas could not gain ground and were rejected as heretical by prominent religious scholars (such as Thomas Aquinas), but did find support in parts of the population (Konrad 1981, 735).

53 Tibesar (1953) and Heras (1992). In order to find out if Joachim's model had influenced the Peruvian Franciscans (directly or indirectly) it would be necessary to know more about the religious views of the individual missionaries (who are listed in Tibesar 1953, ch. 1; also 
the three "status" - reconceptualized by the Franciscans or reinterpreted directly on the basis of Joachim's ideas - might have gained enough influence and feedback among the indigenous population so as to be responsible for the formation of a three-partite history, derived from the Trinity, which is still alive today.

It should be observed, however, that this view of a chronological Trinity is not the only one in the Andes with respect to this phenomenon. In the same village of Pinchimuro the image of Pachamama is one of a female Trinitarian deity:

Kay pacha paqarimantan kay Pachamamaqa niq kasqa: "Ñuqan kani Santa Tirra, Uywaq, ñuñuq, ñuqan kani. Pacha Tirra, Pacha Nusta, Pacha Virgen ñuqa kani," niq kasqa. ...

Kay Santa Tirrapin tiyan panpa ukhupi kimsantin pirsuna - Pacha Tirra, Pachamama, Pacha Nusta.
From this beginning of the world this Pachamama used to say: "I am the Holy Earth, the Nurturer, the Breastfeeder I am. World ${ }^{54}$ Earth, World Princess, World Virgin I am", she used to say. ...

She lives in this Holy Earth, inside, three persons together World Earth, World Mother, World Princess.

(Gow and Condori eds. 1976, 9; translation SDS.)

In this testimony Pachamama is clearly three in one. The pan-Andean word pacha is used for the underlying basic concept, whereas the different "persons" assigned to it are in Spanish and Inca terminology. The narrator uses the expression kimsantin and the word persona which were already employed by the colonial priests to describe the elements of the Christian Trinity (cf. section 3.2.2). The fact that they are used until the present in the catechisms means that the population is still continuously exposed to them, which may make it easier to incorporate these words and concepts into traditional Andean belief forms. A Trinitarian Pachamama does, of course, elevate this female Andean deity and principle of life and fertility to a very important status, equalizing her with the male Christian Trinitarian god.

Córdova Salinas [1651] 1957). It can certainly not be found in Oré's cántico on the Trinity ([1598] 1992, Primer cantico, fol. 69v-72r; see above, section 3.3).

54 I have translated pacha by 'world' because this English word comprises more of what pacha implies than 'earth'. 


\section{Conclusion}

It has become clear that the Andean people have integrated the concept of a god that consists of three persons into their world, but it seems that the colonial priests' rhetorical efforts had an ambiguous effect, probably because they explained the concept of the Christian Trinity in relatively abstract terms, accompanied by loanwords. Whilst on the whole the terminological inventory varied little, difficult and sometimes erroneous syntactic structuring made an unequivocal understanding difficult. Moerover, the use of certain discourse devices available in Quechua (such as CODM/VODM, verbs of transformation) led to the possibility of an ambiguous or even Andean interpretation of the Christian concept.

With all this, we might expect confusion as the main outcome of several hundreds of years of efforts to explain the Christian Trinity to the Andean population. But over the centuries new images have emerged: it seems that for the Andean people it was more plausible and comprehensible to believe in a temporal sequence of a god father and his son, whose birth is celebrated every year again and may therefore have had a considerable impact on understanding the father and the son as markers of two eras. According to colonial sources and studies interpreting them, the Andean people had an understanding of different eras in which mankind developed ${ }^{55}$ (although one has to be careful in taking it for granted that such a system was properly Andean because we lack prehispanic native information and cannot be certain if and how much Fiore's or the Franciscans' or other concepts influenced early colonial texts). So what we find on the one hand is that the Christian multiple god has been periodized in Andean religion, with the contemporary Andeans incorporating him in their own way into the development of the world as seen in eras. On the other hand, nowadays we also find a Trinitarian concept of an indigenous deity, Pachamama, which seems to be the outcome of the continuous teaching of the catechism through the centuries. This means that the adoption of Andean concepts and language resources resulted in different reception strategies, such as the creation of new hybrid concepts based on Andean as well as Christian belief forms, but also the accommodation of Christian beliefs in their own religious system.

With respect to the colonial period, we can only speculate as to the didactic means which were used to teach this aspect of Christianity; it is possible that theater plays and

55 Betanzos ([1551] 1987, cap. I, p. 11-12), Pachacuti Yamqui ([ca. 1613] 1995, fol. 3r-6r, p. 615), Guaman Poma ([ca. 1615] 2001, 22-32). Cf. Barnes (1996), Dedenbach-Salazar Sáenz (1995). 
songs had more influence on the indigenous mind than sermons and other catechetical texts about the Trinity. It is also interesting that the multiple indigenous deities do not seem to have influenced the image of the Trinity in the Andes as much as the chronologization, be it derived from Joachim of Fiore or from the Franciscans. A reason for this may be that multiple deities were not that frequent a phenomenon in the Andes.

We do not, of course, know what impact the 'real' behavior of the Christian priests in their daily practice had on the indigenous population ${ }^{56}$, nor is it possible to judge the influence visual means, such as paintings, had on the Andean population. But from the evidence presented here it is possible to conclude that, whilst the Christians may have thought that they could explain their Trinity to the Andean people better by using the Quechua language, it was exactly this adoption of Andean language resources and concepts which made it easier for the indigenous people to accommodate Christian beliefs, once presented to them in their language, in their own religious framework.

Although the linguistic data are not perfectly conclusive because they reflect a theory rather than a practice, they do provide us with a good impression of how the priests went about using indigenous languages in their catechization efforts and how they may have succeeded not only in confusion, but also in an acceptance and modification of Christian religious phenomena in the Andean religious world. This means that the missionary usage of indigenous languages in certain ways contributed to shaping modern religious belief forms in the Andes.

56 Cf. Guaman Poma's ironical and mostly negative presentation of Christian priests, their sermons and their behavior (Guaman Poma [ca. 1615] 2001, 623-626; for interpretive approaches of Guaman Poma's sermons see Adorno 1991, 166-167; Poupenay-Hart 1996, 198; Dedenbach-Salazar Sáenz 2004; 2013). 


\section{Acknowledgments}

I would like to thank those colleagues who read earlier versions of this article and commented on it, especially Lindsey Crickmay, Tristan Platt, Nancy Farriss, Fernando Moreno and Brian Murdoch.

\section{The author}

Sabine Dedenbach-Salazar SÁEnz is Senior Lecturer at the University of Stirling (Scotland, UK). Her research interests centre on the Andean languages, esp. on Quechua ethnolinguistics, and which role these languages have played in the Christianisation process. Among her recent books is the volume she edited on $\mathrm{La}$ transmisión de conceptos cristianos a las lenguas amerindias: Estudios sobre textos y contextos de la época colonial (Sankt Augustin: Academia Verlag, 2016) and her study El Tratado de los errores de Francisco de Ávila en comparación con el manuscrito quechua de Huarochirí. Estudio analítico y transcripción comparativa. (St. Andrews: St. Andrews University, Centre for Amerindian, Latin American and Caribbean Studies, 2016).

(Email: sd39@stir.ac.uk, sdedenbach@hotmail.co.uk; Internet:

http://www.dedenbachsalazar.stir.ac.uk; http://rms.stir.ac.uk/converisstirling/person/11643.) 


\section{Bibliography}

A threefold deity in stone. ca. 500 BC. Sculpture. Archaeological-ethnographic collection [BASA] of the Department for the Anthropology of the Americas, Bonn University.

Acosta, José de. [1577] 1984/1987. De procuranda indorum salute. Eds. Luceano Pereña et al. 2 vols. Corpus Hispanorum de Pace 23 \& 24. Madrid: Consejo Superior de Investigaciones Científicas.

— [ [1590] 1954. Historia natural y moral de las Indias. In Obras, by José de Acosta. Ed. Francisco Mateos, 1-247. Biblioteca de Autores Españoles 73. Madrid: Atlas.

Adelaar, Willem F. H. 1994. A grammatical category for manifestations of the supernatural in early colonial Quechua. In Language in the Andes, eds. Peter Cole, Gabriella Hermon, and Mario Daniel Martín, 116-125. Occasional Monographs in Latin American Studies, No. 4. Newark, Delaware: University of Delaware, Latin American Studies Program.

Adorno, Rolena. 1991. Guaman Poma: Literatura de resistencia en el Perú colonial. Colección América Nuestra, América Colonizada, 36. México: Siglo Veintiuno. [Original in English: Guaman Poma: Writing and resistance in colonial Peru, Austin 1986.]

Andrews, Jean. 2005. Painting and prohibition in the viceroyalty of Peru: The blessed Trinity. In Antes y después del Quixote en el cincuentenario de la Asociación de Hispanistas de Gran Bretaña e Irlanda, Valencia, 2005, eds. Robert Archer, Valdi Astvaldsson, Stephen Boyd and Michael Thompson, 151-161. Biblioteca Valenciana. Valencia: Generalitat Valenciana.

Anonymous Cuzqueño. ca. 1720-1740. La Trinidad entronizada como tres figuras iguales. Oil painting, Museo de Arte de Lima (Internet:

http://190.12.86.155/coleccionvirtual/view/objects/asitem/137/38/primaryMakerasc?t:state:flow=25b21e12-a715-4ac3-80e7-2388b380551f). Retrieved from: https://commons.wikimedia.org/wiki/Category:Google Art Project works by C uzco_School\#/media/File:Anonymous_Cusco_School -

The Enthroned Trinity as Three Identical Figures - Google Art Project.jpg (both accessed 30 June 2016).

Anonymous Cuzqueño. ca. 1750-1770. Trinidad trifacial. Oil painting, Museo de Arte de Lima (Internet:

http://190.12.86.155/coleccionvirtual/view/objects/asitem/137/40/primaryMakerasc?t:state:flow=7fcc01f3-0458-4966-bd38-41368ebd0877). Retrieved from: https://commons.wikimedia.org/wiki/File:Anonymous_Cusco_School_The Enthroned_Trinity as Three_Identical_Figures_-_Google_Art_Project.jpg (both accessed 30 June 2016).

Arriaga, Pablo José de. [1621] 1968. Extirpación de la idolatría del Pirú. In Crónicas peruanas de interés indígena, ed. Francisco Esteve Barba, 193-277. Biblioteca de Autores Españoles 209. Madrid: Atlas. 
Arte, y vocabulario en la lengua general del Peru llamada quichua, y en la lengua española: el mas copioso y elegante que hasta agora se ha impresso. 1586. En los Reyes [Lima]: Antonio Ricardo. Copy of the Biblioteca Nacional de España, digitzed in the Biblioteca Digital Hispánica. Retrieved from: http://bdh.bne.es/bnesearch/detalle/4205294 (accessed 5 July 2016).

Avendaño, Fernando de. 1649. Sermones de los Misterios de Nvestra Santa Fe Catolica, en lengva castellana, y la general del Inca. Primera y segunda parte. Lima: Jorge López de Herrera.

Barnes, Monica. 1996. The ages of man and of the world according to Hieronymo de Chaues of Seville and Felipe Guamán Poma de Ayala of Peru. In Beyond indigenous voices, LAILA/ALILA 11th International Symposium on Latin American Indian Literatures (1994), ed. Mary H. Preuss, 83-88. Lancaster, California: Labyrinthos.

Barraza, Jacinto. [17th century] 1937. Misión especial a la gran laguna de Chuquito sus riveras, e islas pobladas de gente bárbara, in "Paliques bibliográficos", by Carlos A. Romero, 196-201, Revista Histórica (Lima), vol. XI: 192-228. [This text renders mainly what the Jesuit Diego de Torres Vázquez wrote.]

Betanzos, Juan de. [1551] 1987. Suma y narración de los incas. Transcripción, notas y prólogo por María del Carmen Martín Rubio. Madrid: Atlas.

Calancha, Antonio de la. [1639] 1972. Crónicas agustinianas del Perú. Ed. Bernardo de Torres. Edición, introducción y notas por Manuel Merino. 2 vols. Biblioteca Missionalia Hispanica, vol. XVII. Madrid: Consejo Superior de Investigaciones Científicas, Instituto 'Enrique Flórez', Departamento de Misionología Española.

Catalèg d'escultura i pintura dels segles XVI, XVII y XIII. 1996. Època del Renaixement i el barroc. Fons del Museu Frederic Marès 3. Barcelona: Ajuntament de Barcelona.

Catechismus ex Decreto Concilii Tridentini ad Parochos PII V. et Clementis XIII. Pont. Max. 1567. Köln: Henricus Aquensis.

Catechismus Romanus. See Catechismus ex Decreto Concilii Tridentini.

—. See The Roman Catechism

Cohen Suarez, Ananda. 2013. Painting Andean liminalities at the church of Andahuaylillas, Cuzco, Peru. Colonial Latin American Review 22 (3): 369-399. Link: http://dx.doi.org/10.1080/10609164.2013.851323 (accessed 04 April 2016).

Córdova Salinas, Diego de. [1651] 1957. Crónica franciscana de las provincias del Perú. Notes and introduction by Lino G. Canedo. Publications of the Academy of American Franciscan History, Franciscan Historical Classics 1. Washington: Academy of American Franciscan History. Retrieved from: http://archive.org/details/cronicafrancisca00cord (accessed 6 July 2016).

da Costa Fontes, Manuel. 2005. The Art of Subversion in Inquisitorial Spain: Rojas and Delicado. Purdue Studies in Romance Literatures 30. West Lafayette, Indiana: Purdue University Press. 
Dedenbach-Salazar Sáenz, Sabine. 1994. El arte verbal de los textos quechuas de Huarochirí (Perú, siglo XVII) reflejado en la organización del discurso y en los medios estilísticos. In Andean oral traditions: Discourse and literature / Tradiciones orales andinas: Discurso y literatura, eds. Margot Beyersdorff and Sabine Dedenbach-Salazar Sáenz, 21-49. Bonner Amerikanistische Studien / Estudios Americanistas de Bonn, BAS 24. Bonn: Holos.

—. 1995. Texto y contexto: Releyendo las fuentes andinas a la luz de la pragmática y del discurso. In Etnohistoria latinoamericana: Aportes metodológicos, $48^{\circ}$ Congreso Internacional de Americanistas, Estocolmo-Upsala, 4 al 9 de julio de 1994 (= América Indígena 54/4, México 1994), eds. Sabine Dedenbach-Salazar Sáenz and Iris Gareis, 157-188. México: Instituto Indigenista Interamericano.

— 1997. La terminología cristiana en textos quechuas de instrucción religiosa en el siglo XVI. In Latin American Indian literatures: Messages and meanings, Papers from the Twelfth Annual Symposium, Latin American Indian Literatures Association, ed. Mary H. Preuss, 195-209. Lancaster, California: Labyrinthos.

—. 2003. Die Stimmen von Huarochirí: Indianische Quechua-Überlieferungen aus der Kolonialzeit zwischen Mündlichkeit und Schriftlichkeit - eine Analyse ihres Diskurses. Bonner Amerikanistische Studien / Estudios Americanistas de Bonn / Bonn Americanist Studies BAS 39. CD-ROM. Aachen: Shaker Verlag. Paperback edition 2007. (Also available on the Internet: http://hss.ulb.unibonn.de/2003/0253/0253.htm [accessed 4 July 2016]).

—. 2004. El lenguaje como parodia: Instancias del uso particular del quechua de Guaman Poma y de Pachacuti Yamqui Salcamaygua. Revista Andina 39:227-255. Cuzco.

—. 2013. Entrelazando dos mundos: Experimentos y experiencias con el quechua cristiano en el Perú colonial. Quito: Abya-yala.

Delgado, Mariano. 1992. Inkulturation oder Transkulturation? Der missionstheologische Charakter der Evangelisierung der altamerikanischen Kulturen am Beispiel der Übertragung des abendländisch geprägten trinitarischen Gottesbegriffs. Neue Zeitschrift für Missionswissenschaft 48:161-190.

Doctrina christiana y catecismo para instrvccion de los indios .... [1584] 1985. In Tercer Concilio Provincial de Lima (ed.) 1985, 5-188. [Also on the Internet (digitized copy of the John Carter Brown Library, USA): https://openlibrary.org/books/OL24440872M/Doctrina_christiana y catecismo p ara instruccion de los indios y de las de mas personas que han de s (accessed 5 July 2016). $]^{57}$

Doctrina cristiana en quechua. 1969? Misa completa; oraciones, cantos, letanías y responsos. [Lima]: Editorial Mercurio. [Author: Fray Tadeo?]

\footnotetext{
${ }^{57}$ The books where the Internet site is indicated in square brackets are also accessible through the Internet, but I have consulted the print edition.
} 
Durán, Juan Guillermo. 1984/1990. Monumenta catechetica hispanoamericana (siglos $X V I-X V I I I)$, vol. 1 \& vol 2: Siglo XVI. Publicaciones de la Facultad de Teología de la Pontificia Universidad Católica Argentina "Santa María de los Buenos Aires". Buenos Aires.

Flores de Palacios, H., R. López Raymi, and P. Prendergast Lyons. 1976. Jesucristopa libron. Rímac [Lima]: Edit. Gráf. Industrial.

Furst, Jill Leslie McKeever. 1998. The nahualli of Christ: The Trinity and the nature of the soul in ancient Mexico. RES: Anthropology and Aesthetics, no. 33 (PreColumbian States of Being): 208-224. Stable URL: http://www.jstor.org/stable/20167009 (accessed 4 July 2016).

Gante, Pedro de. ca. 1525-28. Catecismo de la doctrina cristiana. Biblioteca Nacional de España, VITR/26/9. Manuscript. Retrieved from: Biblioteca Digital Hispánica http://bdh-rd.bne.es/viewer.vm?id=0000057904\&page $=1$ (accessed 30 June 2016).

—. [ca. 1525-28] 1970. Catecismo de la Doctrina Cristiana. Facsimile edition. Introducción: Federcio Navarro. [Madrid]: Ministerio de Educación y Ciencia, Dirección General de Archivos y Bibliotecas. [Place and original year from Durán 1984, vol. 1:114, 115.]

Garcilaso de la Vega, Inca. [1609] 2002. Primera parte de los commentarios reales. [Pedro Crassbeeck, Lisboa.] Facsimile edition Madrid: Ediciones de Cultura Hispánica.

- [1609/17] 1960. Comentarios reales (=) Obras completas, by Inca Garcilaso de la Vega, vol. 2: Primera parte and vol. 3: Segunda parte. Biblioteca de Autores Españoles 133 and 134. Madrid: Atlas.

Gareis, Iris. 1987. Religiöse Spezialisten des zentralen Andengebietes zur Zeit der Inka und während der spanischen Kolonialzeit. Münchner Beiträge zur Amerikanistik 19. Hohenschäftlarn: Renner.

Germán de Pamplona. 1970. Iconografía de la santísima Trinidad en el arte medieval español. Madrid: Consejo Superior de Investigaciones Científicas, Instituto "Diego Velázquez".

González Holguín, Diego. [1607] 1975. Gramatica y arte nveva de la lengva general de todo el Peru, llamada lengua qquichua, o lengua del Inca. [Ciudad de los Reyes (Lima)]. [Reimpresión Vaduz - Georgetown.]

_. [1608] 1989. Vocabvlario de la lengva general de todo el Perv llamada lengua qquichua o del Inca. [Ciudad de los Reyes (Lima).] Prólogo Raúl Porras Barrenechea. Presentación Ramiro Matos Mendieta. Lima: Universidad Nacional Mayor de San Marcos. Facsimile of the 1952 edition. Contains addenda.

Gow, Rosalind and Bernabé Condori, eds. 1976. Kay pacha. Tradición oral andina. Biblioteca de la Tradición Oral Andina 1. Cuzco: Centro de Estudios Rurales Andinos "Bartolomé de Las Casas". 
Guaman Poma de Ayala, Felipe. [ca. 1615] 2001. El primer nueva corónica y buen gobierno (1615/1616) (København, Det Kongelige Bibliotek, GKS $22324^{\circ}$ ). Electronic edition directed by Rolena Adorno and Ivan Boserup. Autograph manuscript facsimile, annotated transcription, documents, and other digital resources [and bibliography]. Retrieved from:

http://www.kb.dk/permalink/2006/poma/info/en/frontpage.htm (accessed 30 June 2016). [The page indications refer to the consistently numbered manuscript pages of this edition.]

Hartmann, Roswith. 1991. Christian religious pictographs from the Andes: Two examples. Latin American Indian Literatures Journal 7 (2): 172-191.

Heras, Julián. 1992. Aporte de los franciscanos a la evangelización del Perú. V Centenario Franciscanos Evangelizadores del Perú 5. Lima: Provincia Misionera de San Francisco Solano.

Hoggarth, Leslie. 2004. Contributions to Cuzco Quechua Grammar. Bonner Amerikanistische Studien / Estudios Americanistas de Bonn / Bonn Americanist Studies - BAS 41. CD-ROM. Aachen: Shaker Verlag.

Konrad, Robert. 1981. Chiliasmus III. Mittelalter. In Theologische Realenzyklopädie, vol. VII: 734-737. Berlin: Walter de Gruyter.

Lerner, Robert E. 1988. Joachim von Fiore (ca. 1235-1202). In Theologische Realenzyklopädie, vol. XVII: 84-88. Berlin: Walter de Gruyter.

Lira, Jorge A. 1945. Diccionario kkechuwa-español. Universidad Nacional de Tucumán, publicación no. 369, Instituto de Historia, Lingüística y Folklore, Sección Lingüística XII-2. Tucumán: Universidad Nacional de Tucumán.

Lisi, Francesco Leonardo. 1990. El Tercer Concilio Limense y la aculturación de los indígenas sudamericanos. Estudio crítico con edición, traducción y comentario de las actas del concilio provincial celebrado en Lima entre 1582 y 1583 . Acta Salmanticensia, Estudios Filológicos 233. Salamanca: Ediciones Universidad de Salamanca.

Marzal, Manuel M. 1971. El mundo religioso de Urcos. Un estudio de antropología religiosa y de pastoral campesina de los Andes. Cusco: Instituto de Pastoral Andina.

Mateos, Francisco. 1950a. Constituciones para indios del Primer Concilio Limense (1552). Missionalia Hispanica, año VII, no. 19: 5-54.

—. 1950b. Segundo Concilio Provincial Limense 1567. Missionalia Hispanica, año VII, no. 20: 209-296; no. 21: 525-617.

Mehlmann, Axel. 1991. De Unitate Trinitatis. Forschungen und Dokumente zur Trinitätstheorie Joachims von Fiore im Zusammenhang mit seinem verschollenen Traktat gegen Petrus Lombardus. Inauguraldissertation [PhD thesis], Theologische Fakultät der Albert-Ludwigs Universität Freiburg i. Br. 
Mills, Kenneth. 2007. The naturalization of Andean Christianities. In The Cambridge History of Christianity, vol. 6: Reform and Expansion 1500-1660, ed. R. Po-Chia Hsia, 504-535. Cambridge: Cambridge University Press.

Molloy, Demetrio and Francisco Sutta. 1967. El mensaje de Cristo - Cristop yachachikuynin. Instrucciones misionales quechua-español. Lima: Editorial "Venus".

Oré, Luis Jerónimo de. 1598. Symbolo catholico indiano. Lima: Antonio Ricardo. Retrieved from: https://archive.org/details/simbolo-catholico-indiano-peru (accessed 30 June 2016).

__. [1598] 1992. Symbolo catholico indiano. [Lima: Antonio Ricardo.] Edición facsimilar dirigida por Antonine Tibesar. Colección Ars Historiae. Lima: Australis.

Ortiz Rescaniere, Alejandro. 1980. Huarochirí: 400 años después. Lima: Pontificia Universidad Católica del Perú, Fondo Editorial.

Pachacuti Yamqui Salcamaygua, Juan de Santacruz. [ca. 1613] 1995. Relación de antigüedades deste reino del Perú. Edición, índice analítico y glosario de Carlos Araníbar. Sección de Obras de Historia. México and Lima: Fondo de Cultura Económica.

Pacheco, Francisco. [1638] 1956. Arte de la pintura. Edición del manuscrito original, acabado el 24 de enero de 1638. 2 vols. Preliminar, notas e índices de F. J. Sánchez Cantón. Madrid: Instituto de Valencia de Don Juan; Imprenta y Editorial Maestre.

Pazos, Manuel R. 1951. El teatro franciscano en Méjico durante el siglo XVI. Archivo Ibero-Americano (Segunda época) 11 (42): 129-189. Madrid.

Peña Montenegro, Alonso de la. 1678. Itinerario para parochos de indios .... Leon de Francia: Joan-Ant. Huguetan, y Compañia. [Also on the Internet, 1726 edition: https://archive.org/details/bub gb_EtKeHqtekJcC (accessed 12 July 2016).]

Pérez Bocanegra, Juan [1631] 2012. Ritval formulario, e institucion de cvras , para administrar a los naturales de este reino los santos sacramentos ... [Lima: Geronymo de Contreras]. (Facsimile edition of the copy held in the Biblioteca de la Universidad Nacional de San Antonio de Abad del Cusco.) Eds. Oscar Paredes Pando, Ricardo Valderrama Fernández and Washington Rozas Álvarez. Cusco: Fondo Editorial, Universidad Nacional de San Antonio de Abad del Cusco. [Also on the Internet: digitized copy of the John Carter Brown Library, USA): http://www.archive.org/details/ritualformulario00pr (accessed 12 July 2016).]

PESSCA - Project on the Engraved Sources of Spanish Colonial Art. [s.a.] University of California-Davis; Pontificia Universidad Católica del Perú. Retrieved from: http://colonialart.org/ (accessed 5 July 2016).

Phuturi Suni, Ciprián. 1997. Tanteo puntun chaykuna valen. Las cosas valen cuando están en su punto de equilibrio .... Comp. Dario Espinoza. Lima: CHIRAPAQ. 
Polo de Ondegardo, Juan. [1585] 1985. Instrvccion contra las cerimonias, y ritos que vsan los indios conforme al tiempo de su infidelidad [1585] [adscrito a Polo de Ondegardo, ¿1559?]. In Tercer Concilio Provincial de Lima (ed.) 1985, 253-262. [Also on the Internet (digitized copy of the John Carter Brown Library, USA): https://openlibrary.org/works/OL15480197W/Confessionario_para_los_curas_de i ndios (accessed 5 July 2016).]

Poupenay Hart, Catherine. 1996. Diálogos y sátira en la Crónica de Felipe Guaman Poma de Ayala. Scripture Lleida 11: 191-201.

Ramos Gavilán, Alonso. [1621] 1988. Historia del santuario de Nuestra Señora de Copacabana. Edición Ignacio Prado. Lima: Talleres Gráficos P. A. Villanueva.

Relación de la religión y ritos del Perú hecha por los padres agustinos [1561?]. 1992. Edición, estudio preliminar y notas de Lucila Castro de Trelles. Clásicos peruanos. Lima: Pontificia Universidad Católica del Perú.

Rodríguez, Pedro and Raúl Lanzetti. 1982. El Catecismo Romano: Fuentes e historia del texto y de la redacción. Bases críticas para el estudio teológico del catecismo del Concilio de Trento (1566). Pamplona: Ediciones Universidad de Navarra.

—. 1985. El manuscrito original del Catecismo Romano. Descripción del material y los trabajos al servicio de la edición crítica del catecismo del Concilio de Trento. Pamplona: Ediciones Universidad de Navarra.

Salomon, Frank and George L. Urioste, eds. 1991. See Tradiciones de Huarochirí [ca. $1608] 1991$.

Santo Tomás, Domingo de. [1560] 1951. Lexicon, o vocabulario de la lengua general del Perú [Valladolid]. [Facsimile.] Lima: Instituto de Historia, Universidad Nacional Mayor de San Marcos.

Saranyana, Josep Ignasi and Ana de Zaballa. 1992. Joaquín de Fiore y América. Pamplona: Ediciones EUNATE.

Tavárez, David. 2000. Naming the Trinity: From ideologies of translation to dialectics of reception in colonial Nahua texts, 1547-1771. Colonial Latin American Review 9 (1): 21-47.

Tercer Concilio Provincial de Lima, ed. [1584/85] 1985. Doctrina Christiana y catecismo para instrvccion de indios .... [and] Tercero Cathecismo ... [and other texts]. [Ciudad de los Reyes (Lima): Antonio Ricardo]. [Facsímile del texto trilingüe (del ejemplar de la Biblioteca Diocesana de Cuenca).] Corpus Hispanorum de Pace, vol. 26-2. Madrid: Consejo Superior de Investigaciones Científicas.

Tercero cathecismo. [1585] 1985. Tercero cathecismo y exposicion de la Doctrina christiana, por sermones. In Tercer Concilio Provincial de Lima (ed.) 1985, 333778. [Also on the Internet (digitized copy of the John Carter Brown Library, USA):

https://openlibrary.org/works/OL15435929W/Tercero cathecismo y exposicion de_la_doctrina_christiana_por_sermones (accessed 4 July 2016).] 
The Roman Catechism. 1985. Translated and annotated in accord with Vatican II and post-conciliar documents and the New Code of Canon Law by Robert I. Bradley S.J. and Eugene Kevane. Resources for Catechetical Teachers 2. Boston: St. Paul Editions.

Tibesar, Antonine. 1953. Franciscan beginnings in colonial Peru. Publications of the Academy of American Franciscan History, Monograph Series, Volume 1. Washington, D.C: Academy of American Franciscan History.

Tradiciones de Huarochirí. ca. 1608. Runa yndio ñiscap machoncuna ñaupa pacha .... MS 3169, fol. 64-114. Madrid: Biblioteca Nacional. Facsimile reproduction (printed and on CD-ROM) of the manuscript in: El manuscrito de Huarochirí. Libro sagrado de los Andes peruanos, José Ignacio Úzquiza González, ed. Versión bilingüe quechua-castellano de José María Arguedas. Biblioteca Nueva, Universidad de Extremadura. Madrid: Siglo XXI, 2011.

—. [ca. 1608] 1967. Francisco de Avila. Eds. Hermann Trimborn and Antje Kelm, 1198. Quellenwerke zur alten Geschichte Amerikas aufgezeichnet in den Sprachen der Eingeborenen 8. Berlin: Gebr. Mann Verlag.

—. [ca. 1608] 1987. Ritos y tradiciones de Huarochirí. Manuscrito quechua de comienzos del siglo XVII. Versión paleográfica, interpretación fonológica y traducción al castellano: Gerald Taylor. Historia Andina 12 and Travaux de l'IFEA 35. Lima: Instituto de Estudios Peruanos and Institut Français d'Études Andines.

- [ca. 1608] 1991. The Huarochirí Manuscript. A testament of ancient and colonial Andean religion. Translation from the Quechua by Frank Salomon and George L. Urioste. Annotations and introductory essay by Frank Salomon. Transcription by George L. Urioste. Austin: University of Texas Press.

Trexler, Richard C. 1984. We think, they act: Clerical readings of missionary theatre in 16 th century New Spain. In Understanding popular culture. Europe from the Middle Ages to the nineteenth century, ed. Steven L. Kaplan, 189-227. New Babylon Studies in the Social Sciences 40. Berlin: Mouton.

Trimborn, Hermann. 1960. Mehrfaltige Götter in den Mythen von Huarochirí. Ethnologica (Köln), N.F., 2: 548-551.

Urbano, Henrique. 1980. Dios Yaya, Dios Churi y Dios Espíritu: Modelos trinitarios y arqueología mental en los Andes. Journal of Latin American Lore 6 (1): 111-127.

—. 1993. Las tres edades del mundo. La idea de utopía y de historia en los Andes. In Mito y simbolismo en los Andes. La figura y la palabra, ed. Henrique Urbano, 283-304. Estudios y Debates Regionales Andinos 84. Cuzco: Centro de Estudios Regionales Andinos "Bartolomé de Las Casas".

Valenzuela Márquez, Jaime. 2006. Ambigüedades de la imagen en la cristianización del Perú: Trento, los jesuitas y el Tercer Concilio. Investigaciones Sociales (Lima), año X, no. 17: 491-503. Retrieved from: http://revistasinvestigacion.unmsm.edu.pe/index.php/sociales/article/view/7078/6 $\underline{255}$ (accessed 20 June 2016). 
Vargas Ugarte, Rubén. 1951-54. Concilios limenses 1551-1772, vol. 1/1951: I-V Concilio, vol. 2/1952: VI Concilio, vol. 3/1954: Historia. Lima: Talleres Gráficos de la Tipografía Peruana S.A. Rávago e Hijos.

Visita a la doctrina de Sayán. [1662] 1991. In Amancebados, hechiceros y rebeldes (Chancay, siglo XVII), ed. Ana Sánchez, 73-129. Archivos de Historia Andina 11. Cuzco: Centro de Estudios Regionales Andinos "Bartolomé de Las Casas". 